\title{
A Baláta-tó és madárvilága 2001 és 2018 között
}

\author{
KASZA FERENC
}

E-mail: kaszaf@vipmail.hu

KASzA, F.: The bird fauna of Lake Baláta between 20012018.

Abstract: This paper describes the state of the native moor and nature conservation area as well as the bird fauna. Also the changes of the population in the characteristic plant and vertebrate species.

Keywords: moor, water level, bird fauna, protected plants, vertebrate animals

\section{Bevezetés}

A jelen tanulmány célja, hogy a Baláta-tó és föleg a madárvilágának változását mutassa be a 20. század második feléhez képest. 2001-ben jelentettük meg „A Baláta-láp és gerinces állatvilága, különös tekintettel a madarakra" címü könyvet (KASZA \& MARIÁN 2001). Ez az 1977 és 2000 közötti megfigyeléseimet tartalmazta, de utaltunk MARIÁN Miklós korábbi megfigyeléseire is (MARIÁN 1957). Most a könyvben nem említett egyes 2000-es adatokat is felhasználom.

A fentiek mellett említést teszek a jelentősebb növény és egyes gerinces állat előfordulásokról. A Balátató Belső-Somogyban, Szenta község határában, Kaszó puszta közelében fekvő lápos tó, egy futóhomok területen kialakult szélbarázdában van (SüMEGI et al. 2014). 1942-ben nyilvánították védetté 174 hektár területtel (Földművelésügyi Miniszter 505510/1941.I.b.3.). 2008-tól erdőrezervátum 342 hektár területtel (14/2008 (VIII.23.) KvVM rendelet). A Duna-Dráva Nemzeti Park Igazgatóság és a Kaszó Zrt. közösen kezelik. 2014-ben a zrt. a sásréten és a fúzlápban, valamint a láptóban egy 540 méter hosszú stégrendszert, valamint egy madármegfigyelő tornyot épített. A tanösvényt Dr. Marián Miklós sétánynak nevezték el.

\section{Kutatástörténet}

A terület első kutatója az eddigi vélekedésekkel szemben LÁszLó Gábor geológus volt, aki 1905-1909 között földtani térképezést végzett itt. A kutatások eredményét 1911 és 1915 közötti publikációiban ismertette. A tőzegek kémiai vizsgálatát EMSzT Kálmán végezte (SüMEGI et al. 2014). Az ornitológusok közül BARTHOs Gyula járt elsőként 1905. július 2-án a Balátán (BARTHOs 1967, 2002). A „szigeten” nőtt rekettye bokrokon fészkelő szürkegém kolóniát, beljebb pedig bakcsó és üstökös gém telepet talált. Látott még egy kiskócsagot és két kanalasgémet, tőkés- és cigányrécét, vízityúkot, dankasirályt, erdei cankót, barna rétihéját, nádirigót és nádiposzátát.
2003 júniusában Lubomir ADAMEC cseh botanikus Jan FLISEK-kel és Kamil PASINSZKI-vel végzett aldrovanda megfigyelést. A korábban neki kiküldött aldrovandákat a Cseh Tudományos Akadémia Botanikai Intézetében részben akváriumban, részben egy kis erdei tóban szaporítja. Így a balátai aldrovandának ott van egy génbankja. Elmondása szerint az ausztrál növényeken kívül csak ez pirosodik kifejlett állapotban. A balátai aldrovandáról is említést tesz cikkeiben (ADAMEC 1995, 2005, 2018). Megjegyzem, hogy a piros színü aldrovandáról már MoEsz is írt a brassói Fortyogó mocsárból (MoEsz 1907).

2004 januárjában segítségemmel SüMEGı Pál és társai végeztek talajfúrást és mintavételt a csaknem teljesen kiszáradt és fagyott tómederben (SüMEGI et al. 2014). A láp D-i centrumában méteres tőzeget is találtak. Makrobotanikai, pollenanalitikai, radiokarbonos és üledékföldtani vizsgálatokat végeztek ezt követően. Megállapításuk szerint a jégkor végétöl a vaskor kezdetéig itt nem alakult ki vízborítás. Ekkor vegyes lombozatú tajga vehette körül a területet. Az erdei fenyő is erdőalkotó volt. A tó a vaskor kezdetén alakult ki. A római korban a lápostavi állapot volt a jellemző. A magyar honfoglalás idején záródott láp volt, amely az Árpádkor kezdetére tavi állapotba lépett, és így maradt e kor közepén is. A 13. századra viszont teljesen elláposodott. A nagy kiszáradás miatt akkor volt a tőzegégés is.

A 14. és 15. században ismét tavi állapot alakult ki. A 16-17. századra maximális kiterjedésű mélytó lett. A 18. századtól a Baláta a mai napig lápostó, ahol a láp és a nyílt víz kiterjedése változik (SüMEGI et al. 2014). A fentieket támasztja alá az I. katonai felmérés (1782-85) is. Eszerint: „a Baláto-tónál magas tölgy és bükk [...] található”. „A Baláto-tó inkább mocsár, mint víz, sehol sem lehet lovon átkelni rajta." (DoBAl 1983). Aggodalomra adnak okot az egyre gyakoribb száraz időszakok. A 20. században tudomásunk szerint az 1920-as években és az 1948-1950-es években volt egy majdnem teljes kiszáradás (BORHIDI \& JÁRAI-KOMLÓDI 1959). Megfigyeléseim kezdetétől, 1977-től az 1992-93as években volt egy majdnem teljes kiszáradás. 19992000-ben ezt követte egy általam még soha nem látott olyan magas vízállás, amely a medret teljesen kitöltötte. Az aldrovanda ekkor jelent meg tömegesen. 2001 tavaszán a 2000. évinél már 1 m-el, 2002 márciusában már 1,6 m-el alacsonyabb volt a vízállás. 2003 nyár végére teljesen kiszáradt a tómeder, sehol nem volt még tocsogó sem. Ezt követően lassan emelkedett a vízszint, hogy 2008 (1. ábra) és 2009 őszére ismét teljesen ki- 


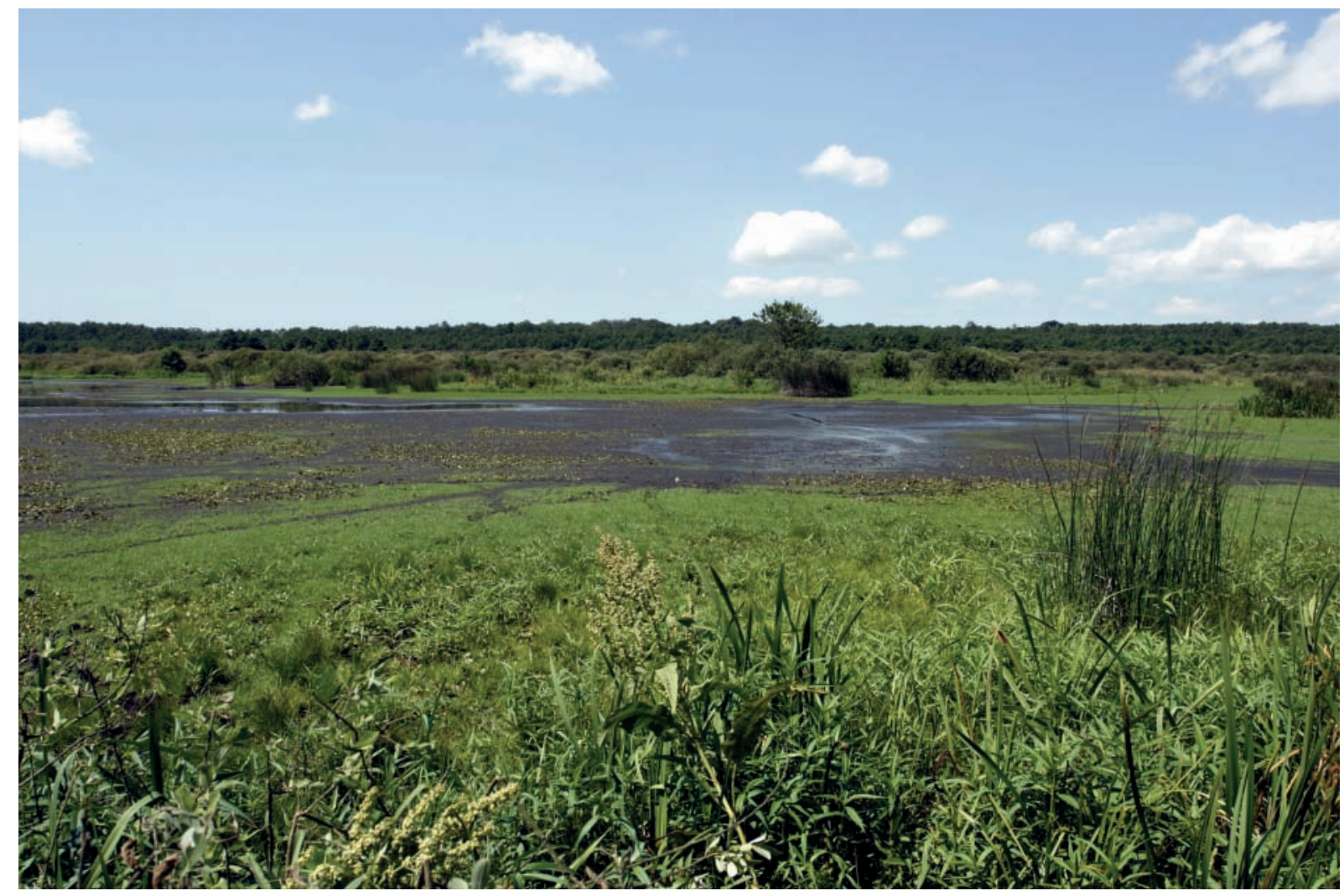

1. ábra. A kiszáradó tó 2008. júliusban

száradjon (2-3. ábra). 2012 őszére ismét volt egy nagy vízszint csökkenés, októberre a nagy tó közepén csak foltokban volt kevés víz. Azóta évenként váltakozva közepes vízszint alakult ki (4. ábra).

MAJER József, M. Bordács Margit, BorHIDI Attila a tó vízminőségének alapállapotát analizálták (MAJER et al. 2002).

TOLD Miklós a terület botanikai értékeiröl és a tó változásairól értekezett (TOLDI 1998). LANSZKI József a Baláta talajszinten élő emlőseit (LANSZKI 2004), ÁBRAHÁM Levente pedig a természetvédelmi terület nagylepkéit mérte föl (ÁBRAHÁm 2016). BÉRCES Sándor a futóbogár faunát tanulmányozta (BÉRCES 2002). BoRICS Gábor, GRIGORSZKY István, PÉTERFI Leontin István, OLDAL Imre, PADISÁK Judit, MOMEU Laura az algaflórához közöltek adatokat (BoRIcs et al. 1998). BoRIcs Gábor, GRIgorszKY István, PADISÁK Judit, SzABó Sándor a dinoflagelláta szervezeteket mutatta be (BoRIcs et al. 2000). KöRMENDI Sándor a zooplankton vizsgálatok eredményeiről számolt be (KöRMENDI 2001, 2002).

\section{Vizsgálati módszerek}

2001 és 2018 között 179 alkalommal jártam a területen. A megfigyelések zömét márciustól októberig végeztem. Ettől függetlenül az év minden hónapjában madarásztam. Általában a kora reggeli és a délelőtti órákban voltam a területen, de néhány alkalommal délután és éjszaka is kint voltam.
Általában a lineáris megfigyelés módszerét alkalmazva jártam körül a tavat. Néhány alkalommal csónakkal jutottam be a nyílt vízre. A madármegfigyelő toronyban is jelentős időt töltöttem megfigyeléssel. A helyszínen részletes feljegyzéseket készítettem. Ezek tartalmazták az időpontokat, az időjárási viszonyokat, a vízállásra, a madarakra, a növényzet állapotára, - benne az érdekesebb növényekre - és néhány gerinces állatra vonatkozó adatokat. A madaraknál feltüntettem azok nemét, korát, példányszámát, a megtalálási biotópját, fészkelését és különleges viselkedését. $A$ jegyzetek alapján naplót és fajokra lebontott kartotékot vezettem.

\section{Eredmények}

\section{Madarak - Aves}

Bütykös hattyú - Cygnus olor (GMELIN, 1729)

A száraz éveket - 2003, 2004, 2007, 2009 - kivéve minden évben költött egy pár. 2001-ben 6 fióka is kikelt. A fészek általában a lápban van és harmatkásából készül. Január és november között láttam.

Nagy lilik - Anser albifrons (SCOPOLI, 1769)

2005.03.14-én figyeltem meg Ny-i irányban repülve 64 példányból álló csapatát. Új faj.

Nyári lúd - Anser anser (LINNAEUS, 1758)

2001., 2005. és 2006. években repültek át csapatosan. 2005.10.29-én 18 úszott a tavon. Közben jött egy átrepülö 26-os csoport is. Ezek közül 9 leszállt az itt lévők- 
höz. 15 perc múlva az összes elrepült. 2001.10.28-án 160 volt a legmagasabb megfigyelt egyedszám.

Fütyülő réce - Anas penelope (LINNAEUS, 1758) 2001. és 2016. között 9 évben tartózkodott itt március, április és szeptember hónapokban 1-32 átvonuló fütyülő réce. Kivétel a 2001. február 09-én látott gácsér. Jellemzőbb volt a 10 alatti példányszám.

Kendermagos réce - Anas strepera (LINNAEUS, 1758) 2013. és 2015. években fészkelési időben - május-július között - is itt maradt. Gácsér és tojó is látható volt 1-5 példányban. 2013.07.19-én 2 vedlőfélben lévő pihent a tavon. Tehát 1-3 pár fészkelt 3 évben. Vonulási időben tízszer láttam.

Csörgő réce - Anas crecca (LINNAEUS, 1758)

A korábban csak átvonulóként jelzett faj észlelései megszaporodtak és a vonulási időszakon túlra is kitolódtak. 2002.06.15-én 1 pár, 2005.07.26-án 1 gácsér úszkált a tavon. 2006.04.15-én párzó csörgő récéket láttam (3 pár). Április 28 és június 16 között 1-2 hím volt látható és hallható. 2011.05.13. és 2011.06.24. között 1-4 gácsér és tojó mozgott a területen. 2012.05.02-én 3 hímet, 1 tojót, július 15-én 4 példányt figyeltem meg. 2014.05.03. és 2014.06.28. között előbb 3 gácsér és 2 tojó, később 1 pár volt látható. Így legalábbis az állapítható meg. hogy a csörgő réce átnyaral a Balátán. 2001től szeptember és november között százas csapatokban (100-600) táplálkozott itt. A réti sas megjelenésekor villámgyors repüléssel cikáztak ide-oda.

Tőkés réce-Anas platyrhynchos (LINNAEUS, 1758) A láp leggyakoribb, 20-30 párban fészkelő récefaja. $A$ jég beálltáig mindig látható. $A z$ őszi és tavaszi időszakokban a korábbi évekhez képest kevesebb tőkés réce tartózkodott itt. 2012.08.29-én volt itt a legnagyobb 600-as csapat.

Nyílfarkú réce - Anas acuta (LINNAEUS, 1758) Csupán 2005.10.29-én láttam 2 példányt.

Böjti réce - Anas querquedula (LINNAEUS, 1758) Az úszórécék közül e faj fészkel még 1-3 párban. Tavaszi nászrepülésüket áprilisban végzik. Tavasszal 2003.04.04én 64, nyár végén 2007.08.27-én 47, ősszel 2005.09.23án 99 volt a legmagasabb megfigyelt egyedszám.

Kanalas réce - Anas clypeata (LINNAEUS, 1758) Vonuló faj a területen. A tárgyalt időszakban összesen 9 alkalommal fordult elő. Március-áprilisra 7, októberre 1 megfigyelés esik. 2011.05.27-én - költési időszakban egy gácsér pihent a vízen. Én 1-7 kanalas récét láttam általában, amint a zsombékok közt szürcsölték a vizet. 2015.04.23-án Mezei Ervin 15-ös csapatot látott.

Barátréce - Aythya ferina (LINNAEUS, 1758) 2002. és 2018. között fészkelési időben - májustól júliusig - 8 alkalommal láttam. 2007.06.09-én 1 pár, a többi esetben gácsér úszott a vízen. 2018.06.02-án 6 gácsér volt a legnagyobb példányszám. Így legalább 1 pár költött, mint új fészkelö faj.

Cigányréce - Aythya nyroca (GÜLDENSTADT, 1770) A tőkés réce után a leggyakoribb költőfaj itt. Természetvédelmi szempontból az egyik legértékesebb költő madarunk. Márciustól októberig láttam. 2010.03.26-án, 2012.06.06-án egyaránt 28 volt a legmagasabb egyedszám. Fiókákat vezető tojókat június elejétől szeptem- ber közepéig láttam. Ez utóbbi 2015.09.12-én volt, amikor 4 fiatal is úszkált a tojó mellett. A költő állomány 5-15 pár volt.

Kontyos réce - Aythya fuligula (LINNAEUS, 1758) 2006.10.28-án 1 pár, 2013.06.19-én pedig 1 gácsér pihent a tavon. Itt nem fészkelt.

Fácán - Phasianus colchicus (LINNAEUS, 1758) 8 évben észleltem fészkelési időben 1-5 példányt. 2007.06.09.-én a sásréten egy tojó 5 fiókát vezetett. Fészkelési időn kívül majdnem minden évben előfordult. 1-2 pár fészkelhetett.

Kis vöcsök - Tachybaptus ruficollis (PALLAS, 1764) Március és szeptember között a leggyakoribb vöcsök faj. Az összes vizes folton táplálkozott. A magas vízállású években a sásréten is megjelent. 2011.06.25-én a Bojsza-tavon vízben álló nyírbokor tövében rakott fészken kotlott. Május közepétől augusztus végéig vezette a vízen a fiókákat. 2006.04.17-én 33 adult volt a legmagasabb példányszám. 2018.07.13-án 21 adult és 25 fiatal vöcsköt számláltam. A vízállástól függően 2-20 pár között ingadozott a költő párok száma.

Búbos vöcsök - Podiceps cristatus (LINNAEUS, 1758) 2001-ben költött 2 pár utoljára. 2001.06.09-én 3 adult madár etetett 7 fiatalt. 2002. és 2018. között a tavaszi vonuláskor (március, április) 5 évben figyeltem meg 1-3 vöcsköt.

Kárókatona - Phalacrocorax carbo (LINNAEUS, 1758) 2001-2002-ben, amíg sok hal volt a tóban (februártól novemberig) táplálkoztak itt a Kis-Balatonról idejáró csapatai. Amíg 2001-ben többtízes számban jöttek, 2002-ben már csak 23 volt a maximum. A legmagasabb megfigyelt példányszámuk 142 volt (2001.07.26.). 2003-tól 2018-ig már csak 9 évben repültek át. Elvétve szállt le rövid időre 1-2 egyed.

Kis kárókatona-Phalacrocoraxpygmeus (PALLAS, 1764) A Bojsza-tavon 2011.07.04-én láttam először 4 halászgató példányt az apadó vízben. Másnap már csak 1 volt ugyanott. Azóta csak 2 átrepülöt láttam. Új faj a területen.

Bölömbika - Botaurus stellaris (LINNAEUS, 1758) 2013 tavaszán Ángyán Antal erdészeti dolgozó hallotta a hangját a lápból.

Törpegém - Ixobrychus minutus (LINNAEUS, 1766) 2001-2002-ben március 15. és július 30. között 1-2 példány mozgott a gyékényesben. Ekkor 1 pár fészkelt. Azóta csak 2015.07.27-én figyeltem meg 1 párat. Valószínüleg ekkor is költött.

Bakcsó - Nycticorax nycticorax (LINNAEUS, 1758) 2001 júliusában, valamint 2002. június 15 és július 27 között 2-3 példány járt ide táplálkozni. Nem fészkelt.

Kis kócsag - Egretta garzetta (LINNAEUS, 1766) 2001.04.29-én és 30-án, valamint 05.19-én táplálkozott 1-1 példány. Április 30-án 2 példány át is repült. Azóta csak 2011.07.14-én fordult elő egy a tó belső szélén.

Nagy kócsag - Egretta alba (LINNAEUS, 1758) 2001ben és 2002-ben februártól novemberig 2-30, 2003-ban áprilistól július végéig 1-13 halászgató nagy kócsag volt rendszeresen a tó szélén, a sásréten és a lápban. 2004 és 2016 között 17 alkalommal figyeltem meg 1-5 példányt, föleg tavasz végén és nyáron jártak ide. 


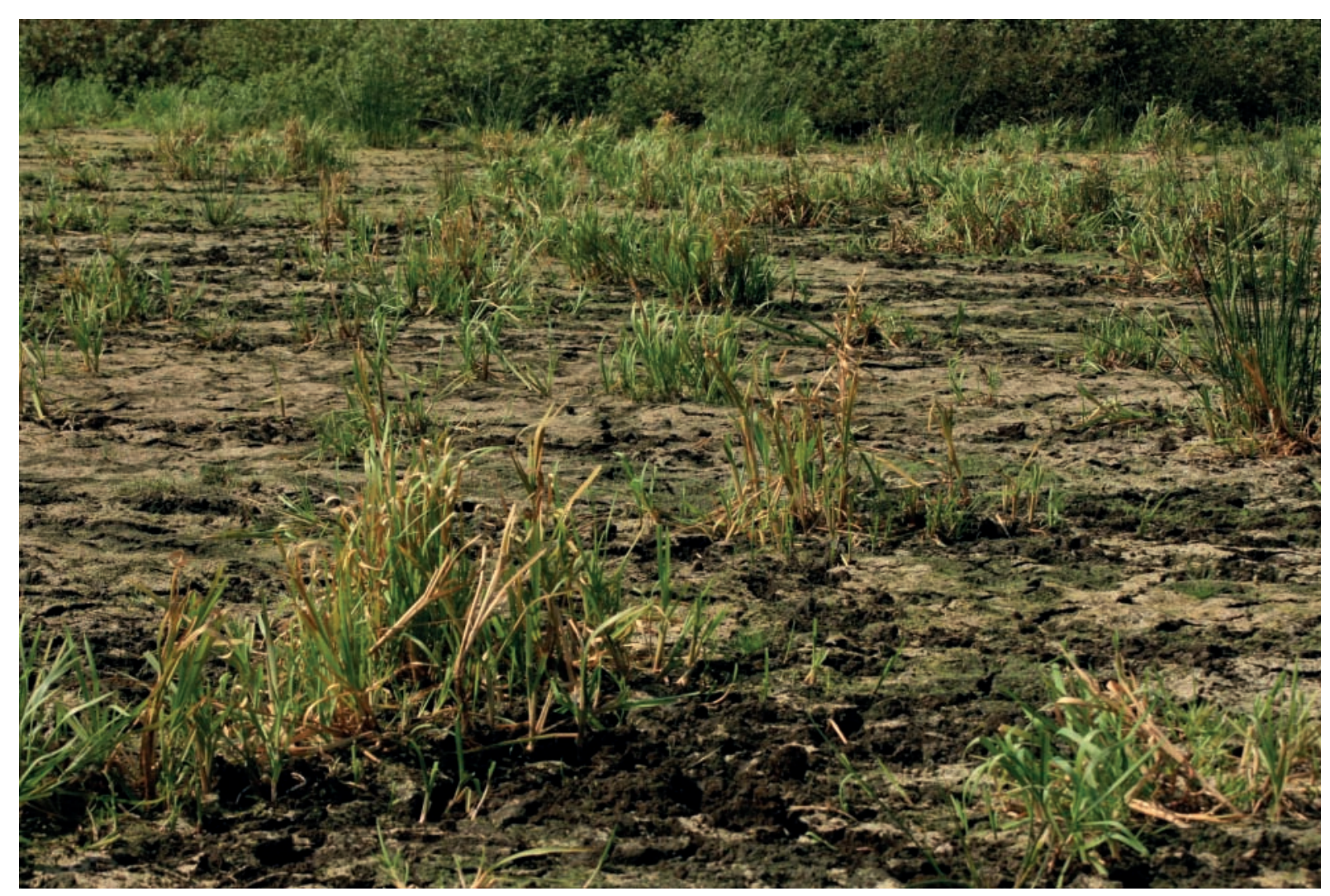

2. ábra. A délnyugati kis tó 2009. szeptember elején

Szürke gém - Ardea cinerea (LINNAEUS, 1758) 2001-2002-ben februártól decemberig 1-16 járt ide rendszeresen. 2003 és 2008 között március közepétől augusztus végéig már csak 1-7 jött. Kivétel 2008.07.14. volt, amikor 23 gém vadászott a sekély vízben. 2009-től 25 alkalommal láttam egyet, kettőt.

Vörös gém - Ardea purpurea (LINNAEUS, 1766) 2001-2002-ben 1 pár költött. 2001.07.25-én 2 adult hordott táplálékot a fiókáknak. 2003 óta nem fordult elő.

Fekete gólya - Ciconia nigra (LINNAEUS, 1758) 2001-ben április végétől június közepéig 1-3 táplálkozott a lápon. 2002. június-júliusban 1-2 példány volt látható. 2006 és 2014 között április és július között 11 alkalommal figyeltem meg 1-5 fekete gólyát.

Kanalasgém - Platalea leucorodia (LINNAEUS, 1758) Ezen ritka vendég 2 egyede 2002.07.27-én jelent meg újra. Bodó Jánossal figyeltük meg, ahogy délután az ÉNy-i vízfoltra szálltak le, majd pár perc múlva az ÉK-i vizes területre szálltak át.

Darázsölyv - Pernis apivorus (LINNAEUS, 1758) A 2000.05.24-i nászrepülés után 2006.05.13-án Puskás Józseffel, Puskás Ágnessel és Engi Lászlóval újabb nászrepülő példányt figyeltünk meg, amint a teste fölött összecsapkodta a szárnyait. 2001 és 2014 között májustól júliusig tizenkétszer fordult elő 1-2 darázsölyv. A fentiekre figyelemmel valószínúleg költött.

Barna kánya - Milvus migrans (BODDAUERT, 1738) 2000.04.13-án a Tuskósi-rétre szállt le. 2001.07.24-én repült át 1 példány. 2011.05.14-én a toronnyal szemben termikelt 10 percig.

Rétisas - Haliaeetus albicilla (LINNAEUS, 1758)

A védett terület tágabb körzetében fészkelő rétisas pár és szaporulatának állandó vadászterülete a tó és a láp. Legmagasabb megfigyelt egyedszáma 2012.08.03-án 9 volt (1 adult és 8 immatur). Amikor méltóságteljesen végig repült a tó fölött É-D-i irányban, akkor a vízi és parti madarak riadtan repültek ide-oda. llyenkor lehetett megbecsülni a csapatok létszámát. A fiatal hattyúk számát alaposan meggyérítette.

Barna rétihéja - Circus aeruginosus (LINNAEUS, 1758) 2001-2002-ben 2 pár, azóta néhány év kivételével 1 pár költött. 2001.04.03-án egy száraz égeren láttam a párzását. A kirepült fiókák állandó sírással kéregették a szülőktől az élelmet. Legnagyobb megfigyelt egyedszáma 6 volt 2002.07.19-én.

Kékes rétihéja - Circus cyaneus (LINNAEUS, 1767) Ezt a nálunk csak telelő ragadozó madarat 2001 és 2003 között háromszor láttam november és április hónapban. 2003.04.04-én 2 hím és 1 tojó vadászgatott a terület fölött.

Hamvas rétihéja - Circus pygargus (LINNAEUS, 1758) 2014.06.04-én K-i irányból jött, átrepülve a tó fölött a Ny-i égerlápba szállt be.

Héja - Accipiter gentilis (LINNAEUS, 1758)

Egy pár költött néhány év $(2004,2006,2009,2010)$ kivételével. 2005.03.12.-én lucfenyőn találtam a fészkét $10 \mathrm{~m}$ magasan a Kis-Baláta mellett. 2008.03.16-án kis vöcsökre, 08.19-én pedig cankóra vadászott. 


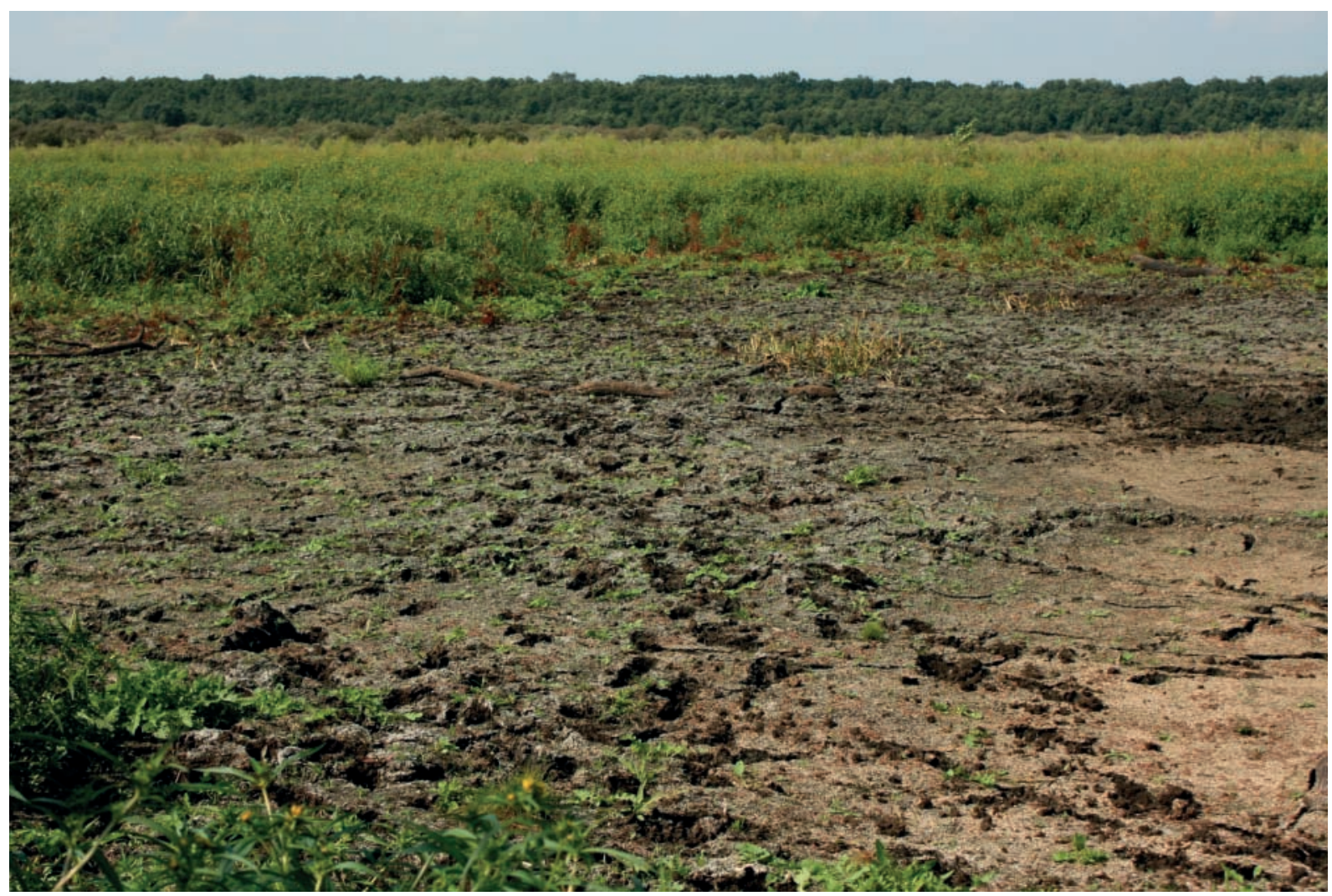

3. ábra. A tó legmélyebb része 2009. szeptemberben

Karvaly - Accipiter nisus (LINNAEUS, 1758)

2005-2006-ban hatszor, 2009 és 2018 között 13 alkalommal figyeltem meg 1-1 példányt, több alkalommal költési időben. Ezért valószínű, hogy alkalmilag költött 1-1 pár. 2011.07.14-én sárgafejü királyka tollakat találtam, ez a karvaly tépése volt.

Egerészölyv - Buteo buteo (LINNAEUS, 1758)

A leggyakrabban megfigyelt ragadozó madár. Egész évben látható a lápon és az erdőben, 3-4 pár költött. Júniusban és júliusban kirepült fiókái kéregették az eleséget. A fészkeket tölgyfán találtam. 2006.05.01-én törékeny gyíkot zsákmányolt.

Vörös vércse - Falco tinnunculus (LINNAEUS, 1758) 2000.04.08-án egy hím repült át Ny-i irányban.

Kék vércse - Falco vespertinus (LINNAEUS, 1766) 2015.04.23-án Mezei Ervin látta leszállni 11-es vonuló csapatát a D-i égerlápon.

Kabasólyom - Falco subbuteo (LINNAEUS, 1758) 2001 és 2018 között tízszer láttam 1-1 kabát. A megfigyelések április vége és szeptember 12 . közé estek. Hat évben költési időben fordult elö, így 1 pár költése valószínű. 2001.04.29-én sárgarigó hím kergette a füzláp fölött.

Guvat - Rallus aquaticus (LINNAEUS, 1758)

1-5 pár rendszeresen fészkelt. Általában a füzlápból lehetett hallani márciustól októberig, malacvisításhoz hasonló hangját. Legnagyobb megfigyelt egyedszáma 2011.07.14-én 7 volt. 2001.07.25-én fiókát etetett. 2002.07.30-án Mezei Ervinnel 1 fiatalt láttunk a rekety- tyésben. 2015.06.10-én 2, 07.27-én 3 immatur példányt figyeltem meg.

Pettyes vízicsibe - Porzana porzana (LINNAEUS, 1766) 2-4 pár rendszeresen fészkelt. 2006.05.25-én Puskás Józseffel és Engi Lászlóval éjszakai körbejárás során 4 revírt találtunk. Áprilistól októberig tartózkodnak itt. 2011.07.14-én és 09.24-én 4 példány hangját hallottam. Ezek voltak a legmagasabb egyedszámok. 2001.07.25én etető adult, 2010.07.22-én 1 immatur példányt láttam.

Kis vízicsibe - Porzana parva (SCOPOLI, 1768) 2007-ben 1 pár fészkelt. 2006.04.15-én a láp ÉK-i részén járva hallottam meg jellegzetes „gek-gek” hangját. A láp és az égeres láperdő találkozásánál egy kis gyékényszigeten sikerült megpillantani. 2007.06.09-én fészkelési időben a füzlápról hallatta hangját. Új faj, és egyben új fészkelő.

Vízityúk - Gallinula chloropus (LINNAEUS, 1758) A vízállástól függően 2-15 pár költött. Márciustól októberig tartózkodott itt. 2011.07.14-én 33-at láttam, ez volt a legmagasabb példányszám. 2010.07.07-én zsombéksás közepébe rakott fészkében 5 tojás volt. Fiatalokat június végétől szeptember közepéig lehetett látni.

Szárcsa - Fulica atra (LINNAEUS, 1758) 3-15 pár költött évente a vízállástól függően. Márciustól októberig voltak láthatók. Recsegő „kork” vagy „krak” hangjuk egész nap hallható. 2006.07.08-án 5 tojásos fészket találtam a kákák között. Fiatalok május végétől júliusig voltak. Legnagyobb egyedszámuk 50 volt. (2011.07.21.) 


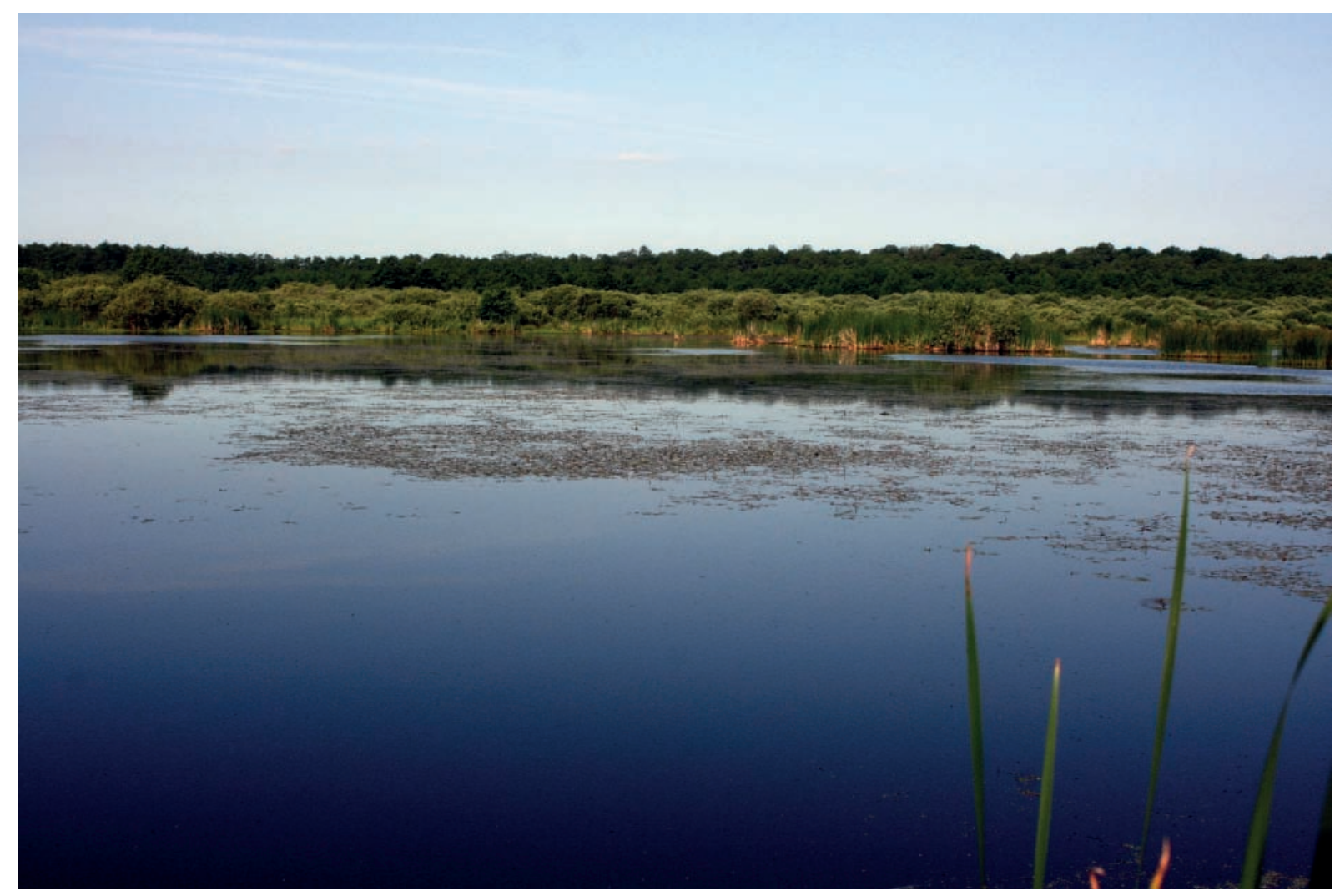

4. ábra. A tó közepes vízállásnál

Daru - Grus grus (LINNAEUS, 1758)

Pitonyák József vadász 2001. március elején mintegy 100 átrepülő darvat látott. Én 2005.03.14-én figyeltem meg az É-i irányban vonuló 15-ös csapatát. Új faj a területen.

Gólyatöcs - Himantopus himantopus (LINNAEUS, 1758) Ez az új kóborló faj 2003.06.28-án jelent meg először. Toldi Miklós és Hóka Sándor figyelték meg ötös csapatát. A nyílt víz fölött röpködtek ide-oda, majd K felé kihúztak. Mezei Ervinnel 2015.05.20-án láttunk a tó fölött röpködő gólyatöcsöt. Ez is elrepült, mert nem talált a leszállásra alkalmas helyet.

Kis lile - Charadrius dubius (SCOPOLI, 1786)

Mint új fajt 2002.07.02-án láttam először. 9 kis lile szedegetett a visszahúzódó víz nyomán maradt iszapban. Másnap már csak a hangját hallottam. 2003.07.07-én 6, 10-én 3, 2008.08.16-án 1 példány tartózkodott a tómederben.

Bíbic - Vanellus vanellus (LINNAEUS, 1758)

Új fészkelő faj. 2001 és 2009 között folyamatosan a területen voltak. 2002.06.15-én 2 fiatalt láttam a lápban. Február és szeptember között volt látható. Legmagasabb egyedszáma 2002.07.27-én 19 volt. 2-10 pár költött.

Havasi partfutó - Calidris alpina (LINNAEUS, 1758) Ezt az új átvonuló fajt Mezei Ervin és Zöldvári Ákos figyelték meg és fényképezték le 2017.08.11-én. Az iszapon táplálkozott.

Pajzsos cankó - Philomachus pugnax (LINNAEUS, 1758) Ezen átvonuló faj 3 egyedét 2002.04.04-én láttam újra az iszapon szedegetve.
Kis sárszalonka-Lymnocryptesminimus(BRÜNNICH, 1764) Új átvonuló faj. 2011.11.03-án a zsombékok közti lápban, a híg iszap tetején üldögélt 2 példány. Egy sárszalonka is ott volt mellettük. Körülbelül 2 méterre megközelítettem őket, ekkor repültek föl.

Sárszalonka - Gallinago gallinago (LINNAEUS, 1758) Egyes években (2001-2002, 2005-2006, 2010) 1 pár költött. 2006.07.08-án egy eleségért síró fiatal mellől repült föl a lápban az adult. Március és november között tartózkodott itt. Legmagasabb megfigyelt példányszáma 11 (2005.06.29.).

Erdei szalonka - Scolopax rusticola (LINNAEUS, 1758) Újabb költését nem sikerült bizonyítani. 2001 és 2011 között 6 alkalommal láttam a március-áprilisi és októberi vonulási időszakban. Varga László vadász áttelelő erdei szalonkát figyelt meg 2000-2001 telén.

Nagy goda - Limosa limosa (LINNAEUS, 1758) Ezt a kóborló példányt 2014.06.28-án figyeltük meg Hóka Szilveszterrel. A DNy-i kistó széléből röpült föl. 1978 után ez volt a második adata.

Füstös cankó - Tringa erythropus (PALLAS, 1764) Ez az átvonuló parti madár 2001 és 2012 között 7 alkalommal jelent meg. A március-áprilisi és a júliusaugusztus-szeptemberi hónapokban fordult elő 1-11 példányban.

Piroslábú cankó - Tringa totanus (LINNAEUS, 1758) Itt csak kóborlóként jelent meg. 2003.07.09-én ketten táplálkoztak az iszapos tómederben. 
Szürke cankó - Tringa nebularia (GUNNERUS, 1767) Ez a parti madár csak átvonul. 2000 és 2012 között júliusban 13, augusztusban 2, június vége felé 1 alkalommal fordult elő. Általában 1-2 példány volt látható. 2012.08.25-én viszont 5 szürke cankó táplálkozott az alacsony vízben.

Erdei cankó - Tringa ochropus (LINNAEUS, 1758) Ez a leggyakrabban előforduló cankó faj. Általában 1-3 példány tartózkodott itt föleg június-július-augusztusban, de egy alkalommal októberben, kétszer pedig novemberben láttam.

Réti cankó - Tringa glareola (LINNAEUS, 1758) 2000 és 2015 között 29 alkalommal figyeltem meg átnyaraló vagy átvonuló 1-21 példányt. 2008. július-augusztusban 11-19-es csapatokban mozgott. 2015.04.29-én 21 réti cankó röpködött a terület fölött. A könyvböl kimaradt az 1989.07.23-i 5 példányos észlelés.

Dankasirály - Larus ridibundus (LINNAEUS, 1766) Nem fészkel. 2001-2003 között 1-26 példány járt ide táplálkozni 8 alkalommal. Azóta csupán ötször repült át 2-41 sirály.

Küszvágó csér - Sterna hirundo (LINNAEUS, 1758) Táplálkozni volt itt 2002.06.15-én és 07.28-án 1-1 példány. 2001 áprilisában 2, 2003 májusában 1 csér repült át.

Fattyúszerkő - Chlidonias hybrida (PALLAS, 1811) 2001 és 2015 között május-június-július hónapokban 1-2 szerkő vadászgatott a nyílt víz fölött rövid ideig.

Kormosszerkő - Chlidonias niger (LINNAEUS, 1758) 2002 és 2013 között 10 alkalommal fordult elő általában 1-2 kormosszerkő. 2011.05.14-én 3, 07.14-én 4 egyedből álló kis csapat jött. Áprilistól júliusig a nyílt víz fölött vadászgattak.

Kék galamb - Columba oenas (LINNAEUS, 1758) 2001 óta rendszeres új fészkelője a területnek. 3-4 pár költött a tölgyesben a fekete harkály készítette odvakban. 2011.04.01-én $6 \mathrm{~m}$ magasan lévő odúba bújt be. Márciustól novemberig lehetett hallani vagy látni általában. 2002. januárban és februárban is elöfordult 1-1 kék galamb.

Örvös galamb - Columba palumbus (LINNAEUS, 1758) 4-8 pár költött változatlanul. Fészkét éger és tölgyfán is találtam. Márciustól novemberig tartózkodott itt. A tavaszi vonulás márciusban, az őszi föleg októberben zajlott. Nagy Endre 2003.03.29-én 400-as, én 2015.03.28-án 74-es, 2015.10.17-én pedig 60-as csapatát látta illetve láttam.

Balkáni gerle-Streptopelia decaocto (FRIVALDSZKY, 1832) 2000. április 10-én 1 kóborló példány volt itt.

Vadgerle - Streptopelia turtur (LINNAEUS, 1758) 2-4 pár fészkelt változatlanul. Májustól augusztusig a nyitottabb erdőrészeken fordult elő.

Kakukk - Cuculus canorus (LINNAEUS, 1758) 2-6 pár él itt. Áprilistól szeptemberig tartózkodik a területen. Legmagasabb megfigyelt példányszáma 6 (2013.05.17., 2017.06.05.).

Macskabagoly - Strix aluco (LINNAEUS, 1758) 1-2 pár költött. 2002.07.27-én éjszaka 3 különböző helyen szólt. 2015.03.12-én tölgyfa áglerepedéséből bújt elő. Másnap este egy pár szólt folyamatosan.
Sarlósfecske - Apus apus (LINNAEUS, 1758)

2002 és 2013 között ötször vadásztak kis csapatai (1-14) a nyílt víz fölött április és július között. 2002.07.27-én 14-es csapatát láttam.

Jégmadár - Alcedo atthis (LINNAEUS, 1758) 2003-ig 1-2 pár fészkelt. 2014.06.07-én ismét költési időben volt itt 1 jégmadár. 2000.05.24-én a fiókáknak eleséget hordó példányt figyeltem meg. Márciustól novemberig tartózkodik itt. 2004 és 2005 októberében vonult át 1.

Gyurgyalag - Merops apiaster (LINNAEUS, 1758) 2001 és 2013 között költési időben vadászott a sásrét fölött 2-4 gyurgyalag. Ezek a bükkpusztai út oldalában, illetve a kaszói homokbányában fészkelők lehettek. 2014 és 2015 nyarán állandóan itt volt 2-3 példány. 2015.10.20-án kidőlt tölgy gyökértányérjában fedeztem föl egy fészekodújukat. 2015 májusában ezt a gyökértányért szétfúrták, és kijutottak a túloldalon. E fa szomszédságában egy nagyobb tölgy gyökértányérjában Hóka Szilveszterrel végül 4 költő pár odúját találtuk meg. Május, augusztus és szeptember hónapokban vonultak át a Baláta fölött. A legnagyobb példányszám 2004.08.07-én 102 volt. Új fészkelő faj.

Búbosbanka - Upupa epops (LINNAEUS, 1758) 2001 és 2016 között - 2 év kivételével - a K-i oldal tölgyesében 1-3 pár költött. 2002.06.16-án és 2011.06.24én eleséget hordott a fiókáknak. 2007.07.02-án egy fiatal példány keresgélt a nyiladékon. Áprilistól júliusig fordul elő.

Nyaktekercs - Jynx torquilla (LINNAEUS, 1758) 2-3 pár rendszeresen költött az égerlápon és az erdőben. Áprilistól júliusig fordult elő. 2012.05.01-én 6 m magasan nyírfában találtam az odúját. Másnap itt párosodtak. 2006.06.16-án a fészekben sziszegő hangot adó fiókákat hallottunk Hóka Sándorral. 2002.07.30-án a zsombékok közt vízben fürdött.

Hamvas küllö - Picus canus (GMELIN, 1788)

1-2 pár fészkelt a területen. Többször láttam eleséget hordó öreg madarakat és kirepült fiatalokat. Az utóbbi években mintha visszaszorítaná a zöld küllő.

Zöld küllő - Picus viridis (LINNAEUS, 1758) 2009 óta fészkelési időben rendszeresen az erdőben tartózkodik egy pár. Egész évben látható volt. Új fészkelö faj.

Fekete harkály - Dryocopus martius (LINNAEUS, 1758) 1-2 pár költött folyamatosan. Egész évben megfigyelhető volt. 2000.04.10-én párzását, 2013.06.22-én 3 kirepült fiókát láttam. Legmagasabb egyedszáma 2002.03.15-én 8 volt.

Nagy fakopáncs - Dendrocopos maior (LINNAEUS, 1758) Ez a leggyakoribb harkályfaj. Egész évben előfordul. Fészekodúját eperfába, szilfába és csertölgybe véste. Táplálékot kéregető fiókáinak hangját májusban és júniusban hallottam. 2018.05.21-én 20 volt a legmagasabb példányszámuk.

Balkáni fakopáncs - Dendrocopos syriacus (HEMPRICH and EHRENBERG, 1833) Valószínüleg Kaszóból kóborolt ide 1-1 példány 2004.06.18-án, 2005.03.12-én és 07.11-én. 


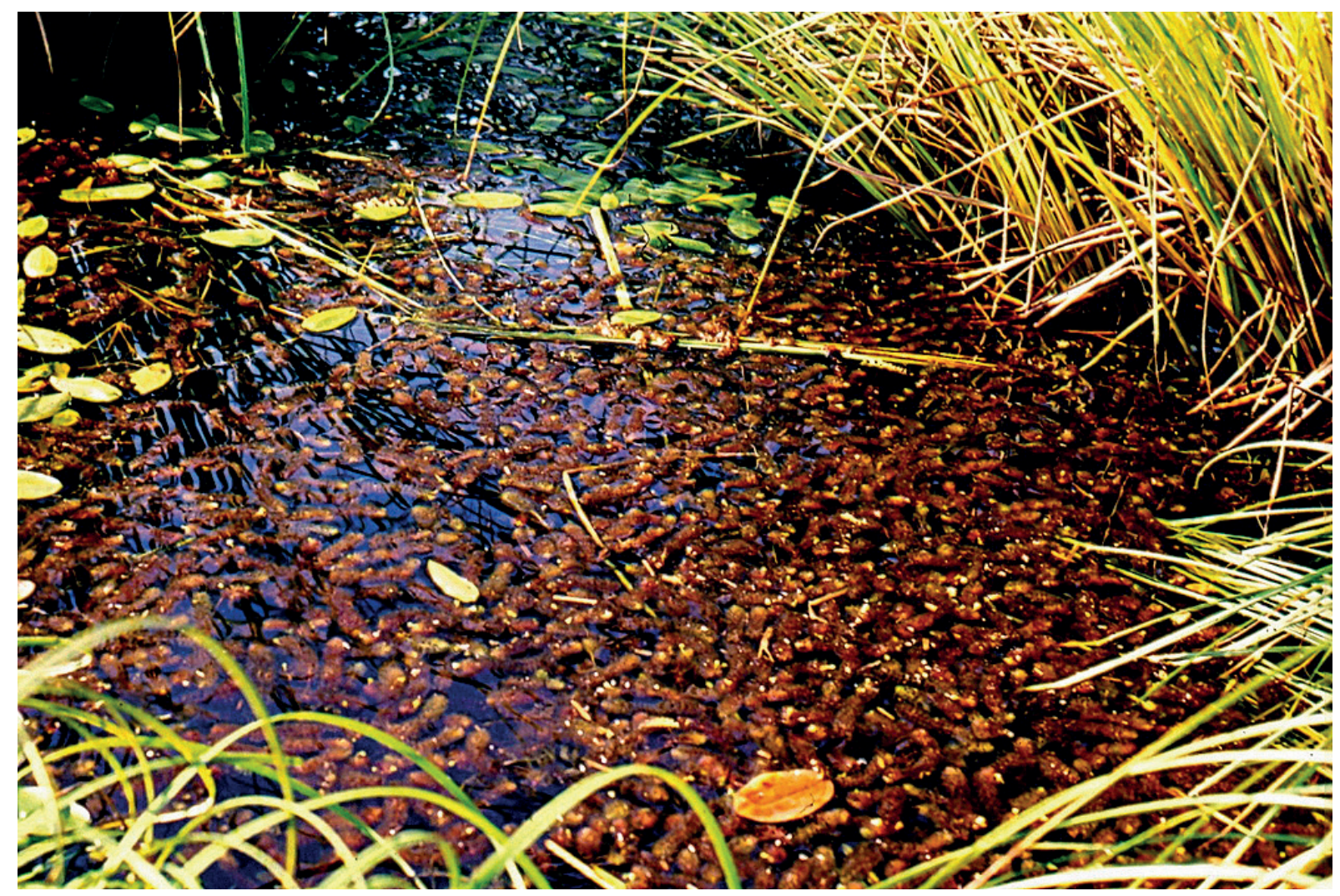

5. ábra. Aldrovandák 2001-ben

Közép fakopáncs - Dendrocopos medius (LINNAEUS, 1758) 1-3 pár költött. Május végén, június elején találtam égerfában és csertölgyben fiókás fészkeit. Az utóbbi években csökkent a számuk.

Kis fakopáncs - Dendrocopos minor (LINNAEUS, 1758) A második leggyakoribb harkályfaj is állandó madár. 3-4 pár költött rendszeresen. 2005.06.03-án és 2016.05.25-én égerfába vájt odúban sírtak a fiókák. 2011.05.27-én 4 kirepült fiatalt etetett a tojó.

Erdei pacsirta - Lullula arborea (LINNAEUS, 1758) 2005.06.06-án a Kis-Baláta melletti müút szélén, telefonoszlopon, 2011.04.01-én a K-i oldalon új telepítésü fiatal tölgyesben énekelt 1-1 pacsirta. Új faj és egyben új fészkelő.

Mezei pacsirta - Alauda arvensis (LINNAEUS, 1758) Hét évben láttam átvonulókat március-áprilisban és szeptember-október-novemberben. Egy alkalommal nyáron, 2005. július 29-én repült át 2 pacsirta. 2006.10.07-én 80 vonult át.

Partifecske - Riparia riparia (LINNAEUS, 1758)

Ide csak táplálkozni jártak. 2000 és 2007 között csupán ötször figyeltem meg április és szeptember között. Legmagasabb egyedszámuk 2002.07.28-án és 2007.07.07én 9 volt. Drasztikusan csökkent a számuk.

Füstifecske - Hirundo rustica (LINNAEUS, 1758) A leggyakoribb fecskefaj március és október között járt táplálkozni vagy éjszakázni a lápra. 2001.07.25-én mintegy ezren éjszakáztak a lápon. 2001.09.30-án kb. 1100 vonult át. 2004-től egyetlen kivétellel - 2011.09.24-i 150 példány - a százat sem érte el a számuk.

Molnárfecske - Delichon urbicum (LINNAEUS, 1758) 2000 és 2018 között csak 4 évben voltak itt táplálkozó vagy átvonuló molnárfecskék. Az átvonulók maximális száma a korábbi 500-ról 140-re csökkent (2000.09.04.,30.). Az utóbbi években pedig az 50-et sem érte el. Április és szeptember között fordultak elő.

Erdei pityer - Anthus trivialis (LINNAEUS, 1758)

Az egyetlen itt fészkelő pityer faj, áprilistól-szeptemberig van itt. Általában a tölgyes és a sásrét találkozásánál zengi revírfoglaló énekét. 2-3 pár fészkelt. 2009.06.20án fiókát féltett. 2015.06.10-én 3 kirepült fiókát etettek az öreg madarak. A legmagasabb megfigyelt példányszámuk 2006.05.01-én és 2002.06.15-én 7 volt.

Réti pityer - Anthus pratensis (LINNAEUS, 1758)

Alkalmi átvonuló március-áprilisban és szeptemberoktóber-novemberben. 2001.02.09-én is volt 4 pityer, lehet, hogy át is telelt. Kis csapatokban (2-7) mozog. A legmagasabb megfigyelt egyedszámuk 2005.10.29én 8 volt, ebböl 3 csak átrepült.

Havasi pityer - Anthus spinoletta (LINNAEUS, 1758) Ez az őszi és tavaszi vonuló, illetve áttelelő pityer faj csupán 2 alkalommal fordult elő. 2004.01.17-én 1, 2005.03.12-én 2 példány keresgélt a jégen, illetve a befagyott tómederben.

Sárga billegető - Motacilla flava (LINNAEUS, 1758) Csak 5 alkalommal fordult elő vonulásban. 2009.04.25én egy pár hímje zengte revírfoglaló énekét, de később már nem láttam. 2004.04.14-én szintén két billegető 
volt itt. Egyszer júliusban, kétszer augusztusban táplálkozott itt 1 illetve 3 billegető.

Hegyi billegető - Motacilla cinerea (TANSTAL, 1771) 2000.07.25-én 1 példány táplálkozott a víz szélén. Barázdabillegető - Motacilla alba (LINNAEUS, 1758) 1-2 pár költött a megfigyelőtorony sarkaiban, illetve a kisvasút Bojsza megálló épületének teteje alatt. Fészkeit tojásokkal és fiókákkal májustól júliusig találtam. 2008.07.18án 8 billegető táplálkozott az apadó tó szélén.

Ökörszem - Troglodytes troglodytes (LINNAEUS, 1758)

5-15 pár költött évenként a tölgyesben és az égerlápon. Fészkét gyakran rakta a kidőlt fák gyökértányérjába. 2011.07.14-én gyertyán leváló kérge alá rakta a fészkét $284 \mathrm{~cm}$ magasan. Egész évben itt tartózkodott. Június-júliusban találtam tojásos vagy fiókás fészkeit. 2001.11.03-án 39 volt a legnagyobb megfigyelt egyedszám.

Erdei szürkebegy - Prunella modularis (LINNAEUS, 1758) 2001 és 2018 között az észlelések száma 21-re emelkedett. A vonulás március-áprilisban és szeptember-októberben zajlik. 2018-ban novemberben, 2013ban januárban is a területen volt, valószínüleg áttelelt. 2013.06.29-én az égerláp K-i oldalán sürü bokrosban énekelt. A telefonról lejátszott nászénekre élénken reagált. Így valószínüleg költött.

Vörösbegy - Erithacus rubecula (LINNAEUS, 1758) Az erdőben és az égerlápon 20-40 pár költött, így az egyik leggyakoribb költő madár. 2010.07.07-én 8 fiókás fészkét találtam B odúban. 2007.06.09-én C odúban 3 tollasodó fióka volt. Fiatalokat áprilistól júliusig találtam. Legmagasabb megfigyelt egyedszáma 2011.04.01-én 50 volt.

Fülemüle - Luscinia megarhynchos (BREHM, 1831) 2016.04.17-én vonuló fülemüle énekelt a DNy-i kistó mellett, a csalános égerlápban. 2011 és 2013 között, valamint 2015-ben a K-i oldalon égeres sürü bokrai között őrzött revírt költési időben ugyanazon a helyen. Így alkalmilag 1 pár költött.

Házi rozsdafarkú - Phoenicurus ochruros (S.G. GMELIN, 1779.) Csupán háromszor fordult elő. 2006.10.07-én a megfigyelő toronyból repült ki egy hím. 2010.03.26-án a bokrok közt tojó, 2015.07.29-én egy immatur a sásréten mozgott.

Kerti rozsdafarkú - Phoenicurus phoenicurus (LINNAEUS, 1758) A 2012-es száraz periódusban 10.04-én a Ny-i oldali vízállás száraz medrében egy átvonuló tojó vadászgatott.

Cigánycsuk - Saxicola torquata (LINNAEUS, 1766) Általában 1-3 pár fészkelt $s$ sásréten. Kirepült fiókák május 20-tól július végéig voltak, illetve ekkor etettek az adultok.

Hantmadár - Oenanthe oenanthe (LINNAEUS, 1758) 2003.04.07-én egy átvonuló táplálkozott az erdő szélén. Új faj a területen.

Feketerigó - Turdus merula (LINNAEUS, 1758) 5-20 pár költött. Egész évben látható. Az erdőben és a lápon táplálkozott. Fészkeit is itt találtam. Legmagasabb megfigyelt példányszáma 2013.06.21-én 41 volt.
Fenyőrigó - Turdus pilaris (LINNAEUS, 1758)

Októbertől márciusig mozogtak itt átvonuló illetve áttelelő csapatai 8 évben. Legmagasabb megfigyelt egyedszám 2015.11.20-án 90 volt.

Énekesrigó - Turdus philomelos (C. L. BREHM, 1831) Márciustól novemberig tartózkodtak a területen, 10-20 pár költött. Márciustól júliusig zengte flótázó énekét. 2011.02.09-én 9 példány volt az erdőben. Vagy korán érkezők, vagy áttelelők voltak. Márciustól júliusig költött. Az utóbbi két évben több énekesrigó tartózkodott itt, mint feketerigó. Legmagasabb megfigyelt egyedszámuk 2017.06.05-én 46 volt.

Szőlőrigó - Turdus iliacus (LINNAEUS, 1766)

Októbertől áprilisig 8 évben találkoztam átvonuló vagy áttelelő példányokkal. Számuk 1 és 69 között mozgott. 2011.11.03-án láttam a 69-es csapatukat. Pár rigó már a tavaszi énekét dalolta. Az égerfákról a füzlápba szálltak le inni.

Léprigó - Turdus viscivorus (LINNAEUS, 1758) Általában 1-3 pár költött a tölgyesben. Az őszi és tavaszi vonuláskor emelkedett a számuk az É-ról telelni érkezők miatt. Ilyenkor a fagyöngy termését ették és közben hallatták cserregő hangjukat. A legmagasabb megfigyelt egyedszámuk 2005.03.13-án 15 volt.

Réti tücsökmadár - Locustella naevia (BODDAERT, 1783) A terület legritkábban fészkelő tücsökmadara. 2006.07.08-án a K-i oldal melletti fiatal tölgyesben 2014.06.02-án a tanösvény mellett a sásréten zengte nászénekét 1-1 madár.

Berki tücsökmadár - Locustella fluviatilis (WOLF, 1810) 1-11 pár között változott a fészkelők száma. Április végétől július közepéig hallottam jellegzetes pirregő hangját a lápból. Legmagasabb megfigyelt egyedszáma 2009.06.20-án 11 volt.

Nádi tücsökmadár - Locustella luscinioides (SAVI, 1824) 1-7 pár költött évente a gyékény- és nádszegélyekben. Április elejétől július végéig lehetett hallani a tücsök hangjához hasonló énekét. A legmagasabb megfigyelt példányszáma 2002.06.15-én 7 volt.

Foltos nádiposzáta - Acrocephalus schoenobaenus (LINNAEUS, 1758) Évente 2 és 25 pár költött, az utóbbi időben egyre csökkenő számban. A leggyakoribb nádiposzáta faj. Áprilistól júliusig volt hallható és látható. 2000.07.20-án eleséget hordó, 2002.07.27-én 2 kirepült fiókát etető adult madarat láttam. A legmagasabb megfigyelt egyedszám 2003.05.05-én 33 volt.

Cserregő nádiposzáta - Acrocephalus scirpaceus (HERMANN, 1804) 2000 és 2002 között évente, utána 2005-ben és 2015-ben költött 1-4 pár. Június elejétől július végéig voltak itt éneklő példányok. A legmagasabb megfigyelt egyedszám 2001.06.29-én és 07.25-én 4 volt.

Énekes nádiposzáta - Acrocephalus palustris (BECHSTEIN, 1798) 2009-ben és 2018-ban fészkelt 4-8 pár a sásréten. A legmagasabb megfigyelt egyedszáma 2008.05.21-én 17 volt.

Nádirigó - Acrocephalus arundinaceus (LINNAEUS, 1758) A nádasban és a gyékényesben 3-9 pár költött. Április végétől július végéig uralkodik éneke. Legmagasabb megfigyelt példányszáma 2002.05.25-én 10 volt. 
Barátposzáta - Sylvia atricapilla (LINNAEUS, 1758) Az erdő és a láp leggyakoribb poszátája. 15-35 pár költött. Fészkeit május-júniusban találtam. Amúgy áprilistól augusztusig fészkelt és énekelt. Legmagasabb megfigyelt egyedszáma 2016.05.25-én 39 volt.

Kerti poszáta - Sylvia borin (BODDAERT, 1783)

Fészkelési időben 2006.05.13-án 1 hím énekelt az erdő bokros részén. 2012.05.02-án szintén éneklő hímet találtam, így valószínű 1 pár fészkelése.

Karvalyposzáta - Sylvia nisoria (BECHSTEIN, 1792) 1 pár költött, 2009.05.23-án és 2014.06.04-én énekelt 1-1 hím a füzláp bokraiban.

Kis poszáta - Sylvia curruca (LINNAEUS, 1758) Csupán két alkalommal vonult át 1-1. (2000.04.08., 2013.04.07.)

Mezei poszáta - Sylvia communis (LATHAM, 1783) 2009 és 2018 között csupán 5 évben tartózkodott a területen 1-2 pár fészkelési időben. Egyébként április vége és augusztus vége között énekelt 1-2 hím.

Sisegő füzike - Phylloscopus sibilatrix (BECHSTEIN, 1793) Egyedül 2006 nyarán költött 2 pár a tölgyesben. Egyébként csak az április-májusi és az augusztusszeptemberi vonulási időben lehetett látni 2000 és 2014 között. 2006.04.17-én 10 volt a legtöbb, amit láttam. A korábbi időszakhoz képest csupán 1 évben költött és a vonulók száma is csökkent.

Csilpcsalp füzike - Phylloscopus collybita (VIEILLOT, 1817) A leggyakoribb füzike faj, évente 20-55 pár költött. Áprilisban kezdte a fészekrakást. Júliusban másodszor is költött. Fiókás fészkeket májustól júliusig találtam. A fészkeket alacsonyan, zsombék oldalába vagy szederbokorba rakta. 2010.07.08-án a fészeképítéshez használt mủanyag szál fonódott rá az egyik fióka lábára és ejtette foglyul. Szerencsére időben kiszabadítottam. Márciustól október végéig volt látható. 2016.04.16-án 56-ot számoltam meg.

Fitiszfüzike - Phylloscopus trochilus (LINNAEUS, 1758) 2002 és 2018 között 8 évben költött 1-4 pár. Egyedül 2018-ban fészkelt 4 pár. 2006.05.01-én fészekanyagot gyüjtött az egyik. 2018.06.02-án a Tuskósi-rét szélén égeresben etetett 1 adult madár repülni is alig tudó fiókát. Április elejétől szeptember közepéig tartózkodik a területen. A legtöbb fitiszfüzike, amit láttam 2009.04.24-én és 2013.04.15-én 5 volt.

Sárgafejű királyka - Regulus regulus (LINNAEUS, 1758) 2002., 2003., 2010., 2011. és 2013. években 1-2 pár költött az erdei fenyvesben és a Kis-Baláta melletti lucfenyvesben. 2002.07.27-én 3 frissen kirepült fiókát láttam. 2011.06.24-én és 2013.06.22-én eleségért síró fiatalokat etettek az öreg madarak. Számuk a szeptember-októberi és március-áprilisi vonulási időszakban emelkedett meg. Több évben át is telelt.

2012.07.15-én a legmagasabb megfigyelt egyedszáma 10 volt. Új fészkelő faj.

Szürke légykapó - Muscicapa striata (PALLAS, 1764) 2000 és 2004 között továbbá 2010-től évente 2-5 pár költött. Június és július hónapokban láttam táplálékot hordó öregeket, illetve kirepült fiatalokat. Májustól szeptemberig fordult elő. A legmagasabb megfigyelt egyedszám 201.07.15-én 10 volt.
Kis légykapó - Ficedula parva (BECHSTEIN, 1792) 2013 nyarán 1 pár költött a Bojsza-domb ritkás tölgyesében. Június 22-én egész nap zengte nászénekét. 2012.05.01-én 3 vonuló hím énekelt a Ny-i égerláp fáin. Új faj és egyben új fészkelő.

Örvös légykapó - Ficedula albicollis (TEMMINCK, 1815) A leggyakoribb fészkelő légykapó faj, 20-50 pár között költött. Április elején érkezett, július végéig, augusztus elejéig maradt. Tojásos fészkeket - B odúban - már április végén találtam. A fiókák május-júniusban láthatók a fészekben. Szívesen foglalják el az égerlápra kihelyezett eternit és deszka odúkat. Terjeszkedőben lévő faj, már a Kaszói és Nagybaráti erdőben is fészkel. A legmagasabb megfigyelt példányszáma 2009.04.25én 70 volt.

Kormos légykapó - Ficedula hypoleuca (PALLAS, 1764) Új fészkelő faj. 2005-ben és 2018-ban is költött 1-1 pár az égerlápon. 2005.06.03-án és 06-án, majd 2018.05.21-én és 06.02-án énekelt 1-1 hím. 2013.08.18-án 2, 2015.04.29-én 1 átvonulót láttam.

Barkós cinege - Panurus biarmicus (LINNAEUS, 1758) 2001.07.25-én a nádasból hallatszott csilingelő hangja. Nem költött.

Őszapó - Aegithalos caudatus (LINNAEUS, 1758)

Ez a hosszú farkú apró testű madár 2-6 párban költött a lápban és az erdőben. A fészket március-áprilisban építette tölgyre, rekettyére és szederbokorra $50 \mathrm{~cm}$-től $5 \mathrm{~m}$-ig. A fiókákat áprilisban és májusban vezetgette. Állandó madár. A legmagasabb megfigyelt egyedszám fiókákkal együtt 36 volt.

Barátcinege - Parus palustris (LINNAEUS, 1758) 4-8 pár költött évente. Fészkét március-áprilisban építette. Amíg megvoltak, szívesen használta az eternit $A$ odúkat. Tojásos fészkek áprilisban voltak. A fiókák április-májusban voltak láthatók. Napokkal korábban kezdte a költést, mint a széncinege. Állandó madár. A legmagasabb megfigyelt példányszáma 2011.11.03-án 25 volt.

Búbos cinege - Parus cristatus (LINNAEUS, 1758) 2001 és 2015 között 10 évben költött 1 pár. 2010.03.26án fészekanyagot vitt. Állandó madár, általában az erdei fenyvesben mozgott. A legmagasabb megfigyelt egyedszám 2013.09.13-án 6 volt.

Fenyves cinege - Parus ater (LINNAEUS, 1758) 2000 és 2015 között 3 év kivételével minden évben fészkelt 1 pár. 2006.05.01-én a K-i égerlápon eternit B odúban találtam 9 fiókás fészkét. Május 12-én már csak 4 tollas fióka volt a fészekben. 2010.06.11-én 3 kirepült fiókát etető cinege volt a fenyvesben. Állandó madár. A legmagasabb megfigyelt egyedszám 2006.05.01-én 10 volt.

Kék cinege - Parus caeruleus (LINNAEUS, 1758) A második leggyakoribb cinegefaj. Évente 4-10 pár költ, a legkésőbb kezdi el a cinegék közül a költést. Tojásos fészkét áprilisban, fiókákkal májusban találtam. Állandó madár. A legnagyobb megfigyelt példányszáma 33 (2005.03.11.).

Széncinege - Parus maior (LINNAEUS, 1758)

A leggyakoribb cinegefaj, az erdőben 15-20 pár költ. A fészekrakást és a költést később kezdte, mint a barátcinege, de korábban, mint a kékcinege. A fiókák április- 


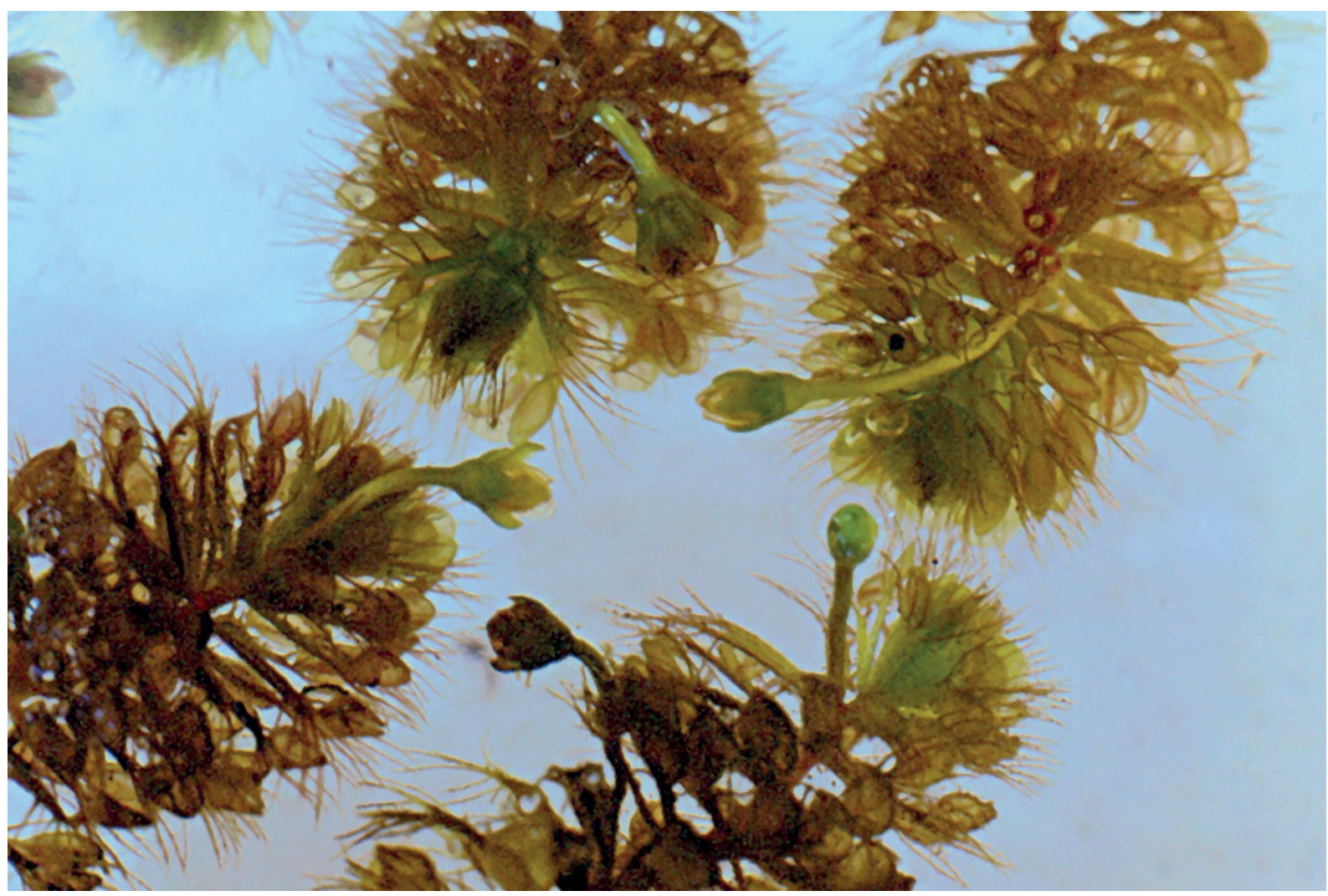

6. ábra. Virágzó aldrovandák 2001-ben

májusban keltek ki. Júniusban egy részük másodszor is költött. A mesterséges odúk többségét e faj foglalta el. Állandó madár. A legmagasabb megfigyelt egyedszáma 54 (2013.06.21.).

Csuszka - Sitta europaea (LINNAEUS, 1758)

Mintegy 10-20 pár költött. 2002.03.15-én egy csuszka sarat hordott a fészekhez. 2005.06.03-án 4 frissen kirepült fiókát láttam. Állandó madár. A legmagasabb megfigyelt példányszám 36 volt.

Hegyi fakusz - Certhia familiaris (LINNAEUS, 1758) 2018. május-júniusban 1-2 pár fészkelt. Új faj és új fészkelő faj.

Rövidkarmú fakusz - Certhia brachydactyla (C.L. BREHM, 1820) 7-15 pár fészkelt. 2001.03.15-én tölgyfa leváló kérge mögé rakta a fészkét $187 \mathrm{~cm}$ magasan. 2001.04.24-én a fenyvesben, mesterséges fészekodúban már tollas fiókák voltak. 2013.04.15-én fészekanyagot hordott a fakusz. Április-májusban 3 fészket is találtam.

Függőcinege - Remiz pendulinus (LINNAEUS, 1758) 2000 és 2016 között 8 évben költött 1-2 pár. 2004.04.03án fészekanyagot vitt. 2002.07.03-án 2 adult madarat követett 3 fiatal. Általában március és július között lehetett látni. Egy alkalommal októberben (2016.10.22.) volt a lápon egy cinege. A legmagasabb megfigyelt egyedszáma 2013.07.19-én 9 volt.

Sárgarigó - Oriolus oriolus (LINNAEUS, 1758) 3-4 pár rendszeresen költött. Áprilistól júliusig tartózkodtak itt. 2016.07.27-én 4 fiatal sárgarigó volt egy tölgyfán.
A legmagasabb megfigyelt egyedszám 2013.06.21-én 8 (4 pár) volt.

Tövisszúró gébics - Lanius collurio (LINNAEUS, 1758) 1-3 pár fészkelt. 2000 és 2018 között csak 2 évben nem láttam. Fészkét galagonya bokorra rakta 123, 124, $121 \mathrm{~cm}$ magasan. A kirepült fiókák június-júliusban mozogtak a sásrét és a füzláp találkozásánál. Májustól szeptemberig tartózkodott itt. Legmagasabb megfigyelt egyedszám 2003.07.19-én 9 volt.

Nagy örgébics - Lanius excubitor (LINNAEUS, 1758) Szeptember végétől márciusig tartózkodott a lápon. 7 évben 16 alkalommal figyeltük meg, ahogy a bokrok tetejéröl vadászott. Mindig egy példány volt itt.

Szajkó - Garrulus glandarius (LINNAEUS, 1758) Állandó madár, 4-5 pár fészkelt. 2001.04.30.-án gyertyánfán volt a fészke $4 \mathrm{~m}$ magasan. 4 tojás volt a fészekben. A kirepült fiatalokat június-júliusban láttam. 2002.07.27-én a fenyvesben szedret evett egy szajkó. Általában repülve szedte le a termést. Ha a fatörzshöz közel volt a szeder, akkor azon kapaszkodva ette le. Legmagasabb megfigyelt példányszám 2005.04.17-én 31 volt.

Vetési varjú - Corvus frugilegus (LINNAEUS, 1758) 2001.03.16-án Hóka Sándor látott 8 átrepülö varjút.

Dolmányos varjú - Corvus cornix (LINNAEUS, 1758) 2000 és 2018 között 3 év kivételével fészkelt egy pár. 2014.06.30-án egy öreg varjú mozgott az erdőben 3 fiatallal. A márciustól júniusig tartó fészkelési időn kívül csak szeptember-októberben fordutl elő 1-3. Legmaga- 
sabb megfigyelt egyedszáma 2016.04.16-án 5 volt.

Holló - Corvus corax (LINNAEUS, 1758)

2000 és 2018 között minden évben és minden hónapban megjelent. A fészkelési időszakban is itt volt. Állandó madár. Legmagasabb megfigyelt példányszáma 2015.10.17-én 17 volt.

Seregély - Sturnus vulgaris (LINNAEUS, 1758)

2001 és 2018 között 13 évben költött 5-30 pár. Áprilistól júniusig tartott a költés és a fiókanevelés. Februártól októberig tartózkodott a területen, de decemberben is előfordult. Legmagasabb egyedszáma 2011.07.14-én 150 volt.

Mezei veréb - Passer montanus (LINNAEUS, 1758) 2011-ben és 2016-ban 1-1 pár költött. 2000 és 2018 között 6 évben volt itt, májustól júliusig, valamint októbertől novemberig. Legmagasabb megfigyelt példányszám 2015.10.17-én 9 volt.

Erdei pinty - Fringilla coelebs (LINNAEUS, 1758) 15-30 pár rendszeresen költött az erdőben és az égerlápon. Áprilistól júliusig két költése is volt. A nálunk fészkelők egy része csak áprilistól októberig maradt. A télre is maradók kiegészülnek az É-ról érkezőkkel. 2001.09.30án 289, 2005.10.29-én 390 pinty vonult át a láp fölött. Ez utóbbi volt egyben a legtöbb megfigyelt pinty. Költési időben 46 volt a maximum 2016.04.16-án.

Fenyőpinty - Fringilla montifringilla (LINNAEUS, 1758) 2000 és 2016 között októbertől márciusig 9 évben fordultak elő áttelelők. Általában tíznél kisebb csapatokban mozogtak. Kétszer, 2005.03.14-én 80-at, 2008.12.14én pedig 40-et láttam.

Csicsörke - Serinus serinus (LINNAEUS, 1758) Valószínűleg a Kaszóban költők jelentek meg alkalmilag. 2000 és 2018 között 5 évben láttam 6 alkalommal júniustól októberig 1-1 csicsörkét.

Zöldike - Carduelis chloris (LINNAEUS, 1758)

2000 és 2018 között 14 évben költött 1-3 pár. Egész évben látható volt. A megfigyelési maximum 2018.09.18.án az égerlápon 17 volt.

Tengelic - Carduelis carduelis (LINNAEUS, 1758) Nem költött a területen. 2000 és 2018 között 7 évben 10 alkalommal fordult elő. Január-április között és októbernovemberben volt itt 1-24 tengelic. Ez utóbbi példányszám 2006.10.28-án volt.

Csíz - Carduelis spinus (LINNAEUS, 1758)

2010 és 2013 között - az egyébként itt csak telelő csíz - 1-2 párban költött. 2010.07.22-én 2 adult és 4 fiatal nyírfán, 2012.07.17-én 4 adult és 7 fiatal égerfán táplálkozott. 2013.04.16-án 21 csíz között több hím nászéneket zengett. 2012.08.28-án 9 tartózkodott itt. Egyébként a nálunk telelő csapatai szeptember végétől április elejéig ették az éger termését. A megfigyelési maximum 2003.11.15-én 200 példány volt.

Kenderike - Carduelis cannabina (LINNAEUS, 1758) A területen nem fészkelt. 2001 és 2009 között 4 évben volt itt 1-4 kenderike júliustól novemberig. A fűzlápon táplálkoztak.

Zsezse - Carduelis flammea (LINNAEUS, 1758)

Ez a nálunk csak téli vendég a tárgyalt időszakban csupán 2013-ban jelent meg. Április 15-én 15 hím és 3 tojó táplálkozott a tölgyesben és a fenyvesben. A hímek énekeltek. Másnapra már csak 1 pár maradt.

Keresztcsőrü - Loxia curvirostra (LINNAEUS, 1758)

Itt csak alkalmilag jelent meg. 2002.07.24-én 4 repült át, majd le is szálltak a fenyvesben. 2003.04.05-én dr. Kókai Károllyal és Cseh Judittal égerfán üldögélő párt láttunk a lápon. 2009.08.26-án 3 tartózkodott a fenyvesben. 2001-ben és 2012-ben átrepült 2-9 keresztcsőrü. 2005.03.12-én Kaszóban etetett 1 pár 3 kirepült fiatalt. Másnap Darvaspuszta közelében fenyvesben láttam a 2 kirepült fiatalt tápláló hímet. Tehát Kaszóban költött.

Süvöltő - Pyrrhula pyrrhula (LINNAEUS, 1758)

Ez a téli vendég 2000 és 2018 között 6 évben fordult elő. Október és március között 4-30 példányos csapatai tartózkodtak itt.

Meggyvágó - Coccothraustes coccothraustes (LINNAEUS, 1758) A tölgyesben és az égerlápon rendszeresen költött 5-20 pár. 2016.04.16-án fészekanyagot gyűjtöttek. 2011.05.27-én 8 pár etetett a tölgyesben. Egész évben látható. $A$ megfigyelési maximum 34 volt 2002.06.15-én és 2000.07.18-án.

Citromsármány - Emberiza citrinella (LINNAEUS, 1758) 2-6 pár rendszeresen fészkelt a tölgyes ritkás részein és a fenyvesben. 2006.07.28-án Hóka Sándor a fenyvesben, mohaszőnyegben $8 \mathrm{~cm}$ mélyen 4 tojással találta a fészkét. 2013.07.20-án egy tojó vitt eleséget a fiókáknak. A legmagasabb megfigyelt egyedszám 12 volt 2005.03.13-án és 2011.05.27-én.

Nádi sármány - Emberiza schoeniclus (LINNAEUS, 1758) A tárgyalt időszakban 1-4 pár fészkelt a láp szélén és a füzlápban, ősszel és télen gyakrabban lehetett látni. A megfigyelési maximum 2005.10.28-án 27 volt.

\section{Adatok a további megfigyelt gerinces állatokról}

\section{Halak - Pisces}

2002.07.03-án Sallai Zoltán halszakértővel csónakon bejártuk a nyílt vizet. Akkumulátoros elektromos halfogóval az alábbi halakat fogtuk.

Kurta baing - Lencaspius delineatus 18 egyed

Razbora - Pseudorasbora parva 43 egyed

Kárász - Carassius carassius 4 egyed

Ezüst kárász - Carassius gibelio 252 egyed

Naphal - Lepomis gibbosus 100 egyed

Réti csík - Misgurnus fossilis 4 egyed

Az ezüst kárászok között volt egy fátyolfarkú is. 2003.06.28-án a száradó mederben a réti csík próbált az iszapon a víztócsa felé átvergődni. Eközben a békák folyamatosan támadtak.

A korábban megfigyelt fajokon felül új faj volt a kurta baing és a razbora. A 2003-as kiszáradással szerintem a halak kipusztultak.

\section{Kétéltüek - Amphibia}

Tarajos gőte - Triturus cristatus

2018.10.06-án Hóka Szilveszterrel találtunk egy példányt az égerlápon.

Pettyes gőte - Triturus vulgaris

2006.05.13-án Puskás Józseffel vízben találtunk egy elpusztult példányt.

Hosszúlábú mocsári béka - Rana arvalis 
2002.03.15-én a láp belsejében mocsári béka petéket találtam. 2008.03.16.-án a Ny-i oldalon a láp belsejében mintegy $8 \mathrm{~m}^{2}$-es területű alacsony vízben kb. 120 béka nászát láttuk -miközben zajlott a peterakás - Puskás Józseffel és Engi Lászlóval.

\section{Hüllök - Reptilia}

Sokszor láttam mocsári teknőst - Emys orbicularis, fürge gyíkot - Lacerta agilis, törékeny gyíkot - Anguis fragilis fragilis, vízisiklót - Natrix natrix. A keresztes vipera - Vipera berus berus - és annak fekete változata - Vipera berus var. prester - csak néha fordult elő az erdőben.

\section{Emlősök - Mammalia}

2002 augusztusában LANSZKI József vizsgálta a talajszinten élő emlősöket (LANSZKI 2004). Megerősítette a mezei cickány - Crocidura leucodon - a csalitjáró pocok - Microtus agrestis - a pirók egér - Apodemus agrarius - a sárganyakú erdei egér - Apodemus flavicollis - az erdei egér - Apodemus silvaticus - a mezei pocok - Microtus arvalis - és az erdei cickány - Sorex araneus - előfordulását. Pirók egeret 2002.03.11-én elpusztulva találtunk. Vakondot 2002.07.08-án szintén elpusztulva láttam. 2001.07.25-én 2 törpe egér fészek volt a harmatkása szárai közt 43 és $73 \mathrm{~cm}$ magasan. 2004.11.02-án csalánra 96 cm magasan rakott fészket találtam. 2001.11.01-én a K-i égerlápon güzüegér - Mus musculus spicilegus - várat figyeltem meg. A kúp $30 \mathrm{~cm}$ magas, az átmérője $82 \mathrm{~cm}$ volt alul. Sok farkasfog termés volt az oldalában. Az aranysakált - Canis aureus többször láttam. A borz - Meles meles - kotoréka lakott volt. Márton Attila vadász a nyusztot - Martes martes - is megfigyelte. Amíg halak voltak a tóban a vidra - Lutra lutra - is rendszeresen itt tartózkodott. 2001.12.18-án két vidra verekedett a jégen. Másnap a jégmentesen tartott bejáratát is megleltük. Vörös rókát - Vulpes vulpes - néhányszor láttam. Puskás Attiláék 2000 körül nyest kutyát - Nycterentes procyonoides - fotóztak. Alkalmanként mókust - Sciurus vulgaris - és görényt - Mustela putorius - is lehetett látni. 2005.07.29.-én a lápréten egy görénytetem volt. A vadmacska - Felis silvestris - is többször előfordult. 2002.07.03-án a K-i égerlápon fa odvában nyivákoló kölyköt talált Mezei Ervin. A mogyorós pele - Muscardinus avellanarius - a mesterséges fészekodúkban többször fészkelt. Vaddisznókat - Sus scrofa - gímszarvast - Cervus elaphus - dámvadat - Dama dama - gyakran, őzet - Capreolus capreolus - ritkábban lehet látni. Száraz időszakban a vaddisznók nagy területeket túrtak föl a lápon.

\section{Egyes növényfajok megfigyelési adatai}

Aldrovanda - Aldrovanda vesiculosa. 2001.02.09én sok hajtásrügy (turion) úszott a víz felszínén a K-i égerlápon. Ez alátámasztja MoEsz azon megfigyelését, hogy egyes években a téli rügy nem száll le az iszapba, hanem a víz felszínén marad (MoEsz, 1907). Március 15-én még több úszott a víz tetején. Április 29-én már a $2-3 \mathrm{~cm}-\mathrm{t}$, némelyiknek az $5 \mathrm{~cm}$-t is elérte a hossza.
A színük ekkor már szép vörösbarna volt (5. ábra). Július 24-én sok virágzó példányt is láttam (6. ábra). November 3-án az apadó vízben rothadva pusztultak. 2003 nyarán csak a K-i oldal semlyékeiben találtunk 100 alatti példányt Toldi Miklóssal, Mezei Ervinnel és Adamecékkel. Az aldrovanda mennyiségének alakulását az elmúlt száz évre Bor Petra dolgozta fel (Bor 2008). Csak megjegyzem, hogy a 2000-es többszázezres becslésemet nem írta le helyesen. 2003 után hol találtuk kis számban, hol nem. Az elmúlt évek magas vízállásának köszönhetően szépen szaporodott. Toldi Miklós becslése szerint 2018ban újra ezer tenyészett, 2019 nyarán ugyanennyit találtunk a rucaöröm - Salvinia natans - szőnyeg között. Úgy láttam, hogy az utóbbi években nyáron már a vízfelszín jelentős részét borítja a rucaöröm. A Balátán kívül 1997-98-ban Böhönye határában talált Lájer Konrád aldrovandát. Itt azóta nem keresték. 2001-ben Molnár Attila Kismarján Kasza puszta közelében a kiszáradó mocsárban lelt rá. Itt azóta sem találták, bár keresték (Mazsu István közlése).

A szíveslevelü hídőr - Caldesia parnassifolia - 2000 óta nem jelent meg.

A fehér tündérrózsa - Nymphaea alba - állományában jelentős volt a változás. 2002.06.15-én figyeltem meg, ahogy egy gímszarvas gyalogolt a nyakáig érő vízben. A borja mellette úszott. A tündérrózsát elérve jóízüen ette annak virágát és leveleit. A borjú ez idő alatt körbe-körbe úszta. Így aztán nem csoda, hogy a 2003as és a 2008-as kiszáradáskor már csak a rizómák maradtak a mederben. 2008 után már nem is voltak láthatók a korábbi több tíz négyzetméter kiterjedésű telepek. 2016-tól lehet újra látni növekedő példányait a stég előtt.

2002 júliusában még egy 40×20m-es telepben tenyészett a sárga tavirózsa - Nuphar lutea - a DK-i nyílt vízben. 2008 után már ezt sem láttam.

Tóalma - Ludwigia palustris. 2001.09.30-án Toldi Miklós mutatta meg a füzlápon 3 telepét. Az ingólápon sikerült derékig lesüllyedni. 2002.04.09-én Borhidi Attilával ugyanitt $67 \mathrm{db} 2-3 \mathrm{~cm}$-es növényt találtunk. 2003.07.06-án és 07.29-én 3 kifejlett tóalma virágzott.

Tőzegeper - Comarum palustre. A 2000-es évek elején az égerszigetek szélében 7 helyen 14 tő virágzott és termést is hozott. 2002.07.30-án egy kis gyékényszigeten is láttam. 2003.07.29-én egy $10 \mathrm{~m}^{2}$-es terjedelmü állomány is volt a lápban. A többit viszont azóta nem találtuk. 2008.05.31-én ez a telep még sok virágot és termést is hozott. 2009.04.24-én már nyoma sem volt. Valószínűleg a szarvas vagy vaddisznó pusztította el. Ezen időpont óta nem találtam.

Tőzegmoha - Sphagnum. Megyeri János szegedi kutató 1963-ban vizsgálta a tó vízifaunáját. A Difflugia acuminata, a Dissotrocha aculeata és a Lecane acus fajok előfordulása miatt megjósolta a tőzegmoha megtelepedését. Az 1990-es években Borhidi Attila és Toldi Miklós meg is találták. 2001 és 2005 tavasza között sok helyen találtam a lápon. Volt közöttük 80 és 300 $\mathrm{m}^{2}$-es is. Ehhez képest 2007.09.15-én már csak keveset láttam. 
Kárpáti sáfrány - Crocus heuffelianus - 1990-ben találta Toldi Miklós és Nagy Tibor. Toldi szóbeli közlése szerint genetikai vizsgálat alapján egy kutató megállapította, hogy ez halvány sáfrány - Crocus vittatus.

Királyné gyertyája - Asphodelus albus. A 90-es évek végén állománya jelentősen visszaesett. Ehhez képest 2010.05.14-én 22, 2011.05.12-én 22, 27-én 24, 2013.05.18-án pedig 47 tő virágzott.

Orchideák - Orchidaceae. A korábban találtakon kívül 2010.06.11-én 4, 2011.05.13-án 2 tő madárfészek békakontyot - Neottia nidus-avis - találtam az ÉK-i gyertyános-tölgyesben. 2009.04.24-én és 2015.04.29-én 4, 2016.04.16-án 3 tő agár sisakoskosbor - Anacamptis morio - virágzott a Tuskósi-rét szélében.

Vidrafü - Menyanthes trifoliata. Mezei Ervin 2000ben mutatta meg az egyik égerszigeten. Azóta egyre inkább nő. 2003 és 2008 májusában is találtam virágozva. A hónap végén pedig termést is hozott. Az ingólápon csak száraz időszakban lehetett megközelíteni.

Lápi vagy kúszócsalán - Urtica kioviensis. A magas vízállásnak köszönhetően 2001-re az égerlápon sok helyen és sok díszlett. A száraz évek jelentősen megritkították, elvétve lehet látni mostanában.

Hamvas vagy rekettyefüz - Salix cinerea. 2007 nyarától sok hamvas füz levele kezdett el száradni. Szerintem az éger levélbogár károsítja a leveleket.

\section{Összegzés}

A Baláta-tó a 20. században csupán háromszor száradt ki, a húszas években, 1948-ban, és 1992-1993-ban. Ehhez képest a 21. század első 18 évében 2003-ban, 2008-2009-ben teljesen kiszáradt, míg 2012 nyarán kiszáradás közeli állapotba került. Az éghajlatváltozás miatt a jövőben számolni kell a gyakoribb vízszintingadozással, és annak a növény- és állatvilágra gyakorolt hátrányos következményeivel. A tárgyalt időszakban a vizsgált területre nézve új faj a nagylilik, a kis kárókatona, a kék vércse, a kis vízicsibe, a daru, a gólyatöcs, a kis lile, a havasi partfutó, a kis sárszalonka, a réti cankó, a hantmadár, a kis légykapó, a hegyi fakusz és a keresztcsőrü. Így a korábbi időszakhoz képest a megfigyelt fajok száma 168-ról 182-re emelkedett. Ebből 2000 és 2018 között 142 fajt észleltünk. Új fészkelők a kendermagos réce, barátréce, karvaly, kabasólyom, bíbic, kis vízicsibe, kék galamb, gyurgyalag, zöld küllö, erdei pacsirta, erdei szürkebegy, sárgafejü királyka, kis légykapó, kormos légykapó, hegyi fakusz, csíz. Összesen 15 faj, így a fészkelő fajok száma 85-röl 100-ra emelkedett. Áttelelt az erdei szalonka, átnyaralt a csörgő réce.

A lúdalakúak közül a bütykös hattyú gyakori fészkelő lett. Új faj az átrepülő nagy lilik. Változatlanul fészkelt a tőkés és a böjti réce valamint a cigányréce. Új fészkelő a kendermagos és a barátréce. Átnyaralt a csörgő réce. Változatlanul fészkelt a fácán. Gyakori fészkelő a kis vöcsök, a búbos vöcsök viszont 2002 óta nem költött. A kárókatonák 2003-tól nem szálltak le, viszont megjelent a kis kárókatona. Gémtelep nem alakult ki. A vörös és törpe gém is csak 2-3 évben költött. A kócsagok, a szürke gém, a fekete gólya és a kanalas gém is csak táplálkozni járt ide. A ragadozó madarak közül a barna rétihéja, a héja, a karvaly, az egerészölyv és a kabasólyom fészkelt. A többi csak átvonult, vagy táplálkozni járt ide. A kék vércse új faj lett. A guvatfélék közül a guvat, a pettyes vízicsibe, a vízityúk és a szárcsa fészkeltek dominánsan. A kis vízicsibe, mint új faj és új fészkelő egyszer költött. A daru, mint új faj néha átrepült. A lile alakúak közül változatlanul költött a sárszalonka. Új fészkelő volt a bíbic. A többiek csak átvonultak vagy kóboroltak. Köztük új fajként a kislile, a havasi partfutó, a gólyatöcs és a réti cankó. A dankasirály, a küszvágó csér, a fattyú és a kormos szerkő csak táplálkoztak itt. A galambfélék közül változatlanul költött az örvös galamb és a vadgerle. Új fészkelő lett a kék galamb. Továbbra is költött a kakukk, a macskabagoly, a jégmadár és a búbos banka, új fészkelő a gyurgyalag. Sarlósfecske csak néha jelent meg. A nyaktekercs, a hamvas küllő, a fekete harkály, a nagy- a közép- és kis- fakopáncs továbbra is fészkeltek. Új költőfaj a zöld küllö, amelyik visszaszorítja a hamvas küllöt. A pacsirtafélék közül a mezei pacsirta még mindig csak átvonul, míg az erdei pacsirta új faj, és új fészkelő. A füsti-, a molnár- és a partifecskék átvonuló, vagy táplálkozó csapatai drasztikusan lecsökkentek. A pityerek és a billegetők közül csak az erdei pityer és a barázdabillegető költött. A többi pityer és billegető csak átvonult. Az ökörszem gyakori fészkelö volt, míg az addig csak átvonuló erdei szürkebegy egyszer költött is. A rigófélék közül változatlanul fészkelt a vörösbegy, a fülemüle, a cigánycsuk, a feketerigó, az énekes rigó és a léprigó. A házi- és a kerti rozsdafarkú, a fenyőrigó és a szőlőrigó csak átvonultak, vagy átteleltek. Új fajként jelent meg vonulásban a hantmadár. Változatlanul fészkelt mindhárom tücsökmadár. Ugyanezt állapítottam meg a foltos, a cserregő és az énekes nádi poszátáról, valamint a nádirigóról. A poszáták közül a barát, a mezei, a karvaly és a kerti poszáta költött, a kis poszáta már csak átvonult. A füzikék közül a csilpcsalp rendszeresen és nagy számban, a fitisz ritkábban és kis számban, a sisegő pedig csak egy évben költött. A sárgafejü királyka mint új költő faj 5 évben költött. A légykapók közül az örvös légykapó emelkedő számban, a szürke légykapó néhány párban költött. A kormos légykapó új fészkelő, a kis légykapó új faj és új fészkelő is lett. A barkós cinege csak kóborolt, az őszapó továbbra is költött. A cinegék közül a barát-, a búbos-, a fenyves-, a kék-, és a széncinege változatlanul fészkeltek. Ugyanez állapítható meg a csuszkáról, a rövidkarmú fakuszról és a függőcinegéröl is. Új faj és új fészkelő lett a hosszúkarmú fakusz. Továbbra is költ a sárgarigó és a tövisszúró gébics illetve áttelel a nagy őrgébics. A varjúfélék közül a szajkó és a dolmányos varjú fészkelt, a holló egész évben itt volt, a vetési varjú egyszer átrepült. A seregély gyakran, a mezei veréb kétszer költött. A pintyfélék közül az erdei pinty, a zöldike és a meggyvágó továbbra is költ. Új költő a csíz. A csicsörke, a kenderike, a tengelic és a keresztcsőrü csak kóboroltak. Ez utóbbi a környéken fészkelt is. A zsezse csak átvonult, a fenyőpinty és a süvöltő áttelelt. A citromsármány és a nádi sármány továbbra is költött.

A halaknál a 2000-es évek elején új faj lett a kurta baing és a razbora. A kiszáradások leginkább a halakat 
sújtják. Ilyenkor szinte az összes kipusztul. A rágcsálók közt új faj a güzüegér. A kétéltüek között a barnavarangyok, a mocsári-, az erdei-, a kecske-, és a tavi békák nagy számban fordulnak elő és nászidőszakban hangjuk betölti a lápot.

A ragadozóknál az aranysakál egyre inkább visszaszorítja a vörös rókát. Új faj a nyestkutya.

A növényeknél átmeneti visszaesés után jelenleg jó az aldrovanda helyzete. Nem láttuk újra a szíveslevelü hídőrt. 2009 óta nem találtuk a tőzegepret. Visszaszorulóban vannak a tőzegmohák, a kúszó csalán. A kárpáti sáfrány genetikai vizsgálat alapján halvány sáfránynak bizonyult. Megerősödött a királyné gyertyájának állománya. Az orchideák közül a madárfészek békakonty és az általam itt még nem látott agár sisakoskosbor előfordulását figyeltem meg.

\section{Köszönetnyilvánítás}

Köszönetet mondok a megfigyelésekhez nyújtott segítségért Hóka Sándornak, Hóka Szilveszternek, Kasza Ferenc Tamásnak, dr. Kasza Péternek, Mezei Ervinnek. $\mathrm{Az}$ adataik átengedését köszönöm Ángyán Antalnak, Hóka Sándornak, Márton Attilának, Mezei Ervinnek, Nagy Endrének, Pitonyák Józsefnek, Sallai Zoltánnak és Varga Lászlónak. A szállásomhoz, étkezésemhez és a közlekedésemhez segítséget nyújtottak Hóka Sándor és családja valamint Kasza Sándor és családja. Az erdei közlekedéshez szükséges engedélyeket köszönöm Horváth Lászlónak, Sashalmi Miklósnak és Tamás Jánosnak. Végül, de nem utolsó sorban köszönöm páromnak Maknics Katalinnak a megfigyelésekhez nyújtott segítséget és a tanulmány legépelését.

\section{Irodalom}

ADAMEC, L. 1995: Ecological requirements and the European distribution of the aquatic carnivorous plant Aldrovanda vesiculosa L. - Folia Geobot Phytotax. Prague 30: 53-61.

ADAMEC, L. 2005: Quoi de nonveau du cote dela recherche sur Aldrovanda? - Dionée 58:22-28.

AdAMEC, L. 2018: Biological flora of Central Europe: Aldrovanda vesiculosa L. - Perspect Plant Ecol. Evol. Syst. 35: 8-21.

ÁBRAHÁM L. 2016: Nagy lepke felmérés a Baláta-tó Természetvédelmi Területén (Lepidoptera: macrolepidoptera). - A Kaposvári RipplRónai Múzeum Közleményei 04:69-90.

BARTHOS GY. 1967: Madárkutatás Erdőgazdaság és Faipar 7.pp 4-5.

BARHTOS GY. 2002: Erdészüdv, vadászüdv! - Erdészettörténeti közlemények LIV. Állami Erdészeti Szolgálat Országos Erdészeti Egyesület Erdészettörténeti Szakosztály Budapest

BÉRCES S. 2002: Adatok a Baláta-tó, természetvédelmi terület futóbogár faunájához (Coleoptera Carabidae) - Somogyi Múzeumok Közleményei 15: 123-128.

BoR P. 2008: A Baláta kincse: az aldrovanda - Élet és Tudomány LXIII 37.pp 1168-1170.

BORHIDI A. ÉS JÁRAI KOMLÓDI M. 1959: Die Vegetation des Naturschutzgebietes des Baláta-sees - Acta Botanica Hungarica 5:259-320.

Borics G., Grigorszky I, PÉterfi L., Oldal I., PAdisák J., MomeU L. 1998: Adatok a Baláta-tó algaflórájához - Hidrológiai Közlöny 78:5-6 pp 276-278.

Borics G., GRIgorszKY I., PADISÁK J., SZABó S. 2000: A Baláta-tó dinoflagelláta flórája és annak sajátosságai - Hidrológiai Közlöny 5: 282-284.

DoBAl A. 1983: Somogy megye az első katonai felvétel (1782-1785) idején - Somogy megye múltjából 14. Kaposvár pp. 89-161.
HADARICS T. És ZALAI T. (szerk.) 2008: Magyarország madarainak névjegyzéke - Magyar Madártani és Természetvédelmi Egyesület, Budapest, $278 \mathrm{p}$.

HARASZTHY L. (szerk.) 1998: Magyarország madarai - Mezőgazda Kiadó, Budapest $441 \mathrm{p}$.

KASZA F., MARIÁN M. 2001: A Baláta-láp és gerinces állatvilága, különös tekintettel a madarakra - Natura Somogyiensis 2., Kaposvár

KöRMENDı S. 2001: Zooplankton vizsgálatok a Baláta-tó különböző élőhelyein - Hidrológiai Közlöny 81:5-6

KöRMENDI S. 2003: Újabb adatok a Baláta-tó zooplankton faunájának ismeretéhez - A Janus Pannonius Múzeum Évkönyve 46-47. pp. 5-12.

LANSZKI J. 2004: Somogyi lápok talajszinten élő emlős faunájának vizsgálata - Állattani Közlemények 89(2): 23-30.

MEGYERI J. 1965: Adatok a Baláta-tó vízifaunájának ismeretéhez - Szegedi Tanárképző Főiskola Tudományos Közleményei 2: 105-114.

MAJER J., M. Bordács M., BorHIDI A. 2002: A Baláta-tó vízminőségének alapállapot felvételezése - Somogyi Múzeumok Közleményei 15: 97-106

MARIÁN M. 1957: A Baláta gerinces állatvilága - Somogyi Almanach I. Kaposvár

MoEsz G. 1907: Adatok az Aldrovanda vesiculosa L. ismeretéhez - Annales Musei Nationalis Hungaria V. pp. 324-399.

MoLNÁR V. A. 2011: Magyarország orchideáinak atlasza - Kossuth Természettár, Kossuth Kiadó

SümegI P., NáfrádI K., Jakab G., Persaits G., Töröcsik T. 2014: A Baláta-tó környezettörténete - A Kaposvári Rippl-Rónai Múzeum Közleményei 3: 5-28.

TOLDI M. 1998: A Baláta-tó botanikai értékei és változások a tavon 1981-1997 között - Kitaibelia III:2. Debrecen pp.10. 
